\title{
Irish Serpukhovian revisited
}

\author{
P. Cózar ${ }^{1}$ I. D. Somerville ${ }^{2}$
}

${ }^{1}$ Instituto de Geociencias (CSIC, UCM), Ciudad Universitaria, 28040 Madrid, Spain. Email: p.cozar@igeo.csic-ucm.es

${ }^{2}$ UCD School of Earth Sciences, University College Dublin, Belfield, Dublin 4, Ireland. Email: ian.somerville@ucd.ie

Correspondence

P. Cózar, Instituto de Geociencias (CSIC, UCM), Ciudad Universitaria, 28040 Madrid, Spain. E-mail: p.cozar@igeo.csic-ucm.es

\section{Abstract}

In this study of Mississippian rocks in Ireland, it is now recognised, based on faunal evidence, that several upper Viséan limestone formations which were previously excluded from the Serpukhovian now belong, in part, to the lower two substages of the Serpukhovian. A reassessment of previous foraminiferal determinations, together with new foraminiferal data, has confirmed that rocks equivalents to the Tarusian and Steshevian substages are present in several sections. In the Slievenaglasha Formation and Magowna Formation (County Clare) and Deer Park Formation (County Meath), Tarusian and Steshevian foraminiferal assemblages are thus recorded. In the Clogrenan Formation (County Carlow), Carganamuck Limestone Formation (County Armagh) and Rockdale Limestone Formation (County Tyrone), Tarusian foraminiferal assemblages are recorded in the upper beds of thick limestone successions. Key foraminiferal and algal taxa characterise each assemblage, which have been correlated with equivalent Serpukhovian strata in the north of England and Scotland. A three-stage evolution is 
recognised in archaediscid foraminifers: from Neoarchaediscus gregorii, followed by Neoarchaediscus postrugosus form 1, and Neoarchaediscus postrugosus form 2, with Neoarchaediscus postrugosus form 1 used to define the base of the Serpukhovian. The recognition of Tarusian and Steshevian foraminiferal assemblages implies that areas of shallow-water platform carbonate sedimentation in Ireland during the upper Viséan (Brigantian) persisted into the early Serpukhovian.

Keywords: ammonoids, Arnsbergian, biostratigraphy, Brigantian, foraminifers, Pendleian

Funding: This research was funded by the Spanish Ministry of Ciencia, Investigación y Universidades (project CGL2016-78738BTE). 


\section{INTRODUCTION}

The Serpukhovian Stage is currently under investigation, as part of the research on establishing a Global Stratotype Section and Point (GSSP) between the Viséan and Serpukhovian (e.g., Richards \& Task Group, 2017), that also marks the boundary between the Middle and Upper Mississippian. For nearly two decades, researchers have considered the conodont Lochriea ziegleri as the best candidate as a marker for the new GSSP of the basal Serpukhovian (Richards \& Task Group, 2003). This implies that the base of the Serpukhovian should be relocated in slightly older levels, within the upper Viséan, than in the former parastratotype of the Serpukhovian in the Zabori'e Quarry of the Moscow Basin (Gibshman, 2003; Skompski et al., 1995). In the last few years, numerous publications have been dedicated to the search for Lochriea ziegleri around the world (see references in Cózar, Vachard, Aretz, \& Somerville, 2019; Nikolaeva et al., in press). However, the supposed synchronous first occurrence of this taxon is still a matter of discussion (e.g., Barham, Murray, Sevastopulo, \& Williams, 2015; Cózar et al., 2019; Herbig, 2017; Nikolaeva et al., in press; Sevastopulo \& Barham, 2014). A significant problem which complicates the study of the first appearance datum (FAD) of this taxon, is the lack of calibration in the international correlations of biozones and regional stages (now recognized as regional substages), used in many countries/basins, compared to the standard chronostratigraphic scale (see Davydov, Korn, Schmitz, Gradstein, \& Hammer, 2012). This calibration is progressing, but slowly, and yet, comparison of the FAD of different species is strongly controlled by traditional biozone/stage correlations, using very diverse types of fauna/flora. Furthermore, not well-constrained biozone correlations are dependent on inferred synchronous faunal dispersion/migrations. Within the studied late ViséanSerpukhovian interval, one of the biggest mismatches in Europe is observed between the base of the Namurian and the base of the Serpukhovian. For many decades, the base of the Namurian was equated with the base of the Serpukhovian (see George \& Wagner, 1972; Wagner \& Higgins, 1979), and even more recently, this correlation has been widely used (Davydov, Crowley, Schmitz, \& Poletaev, 2010; Einor, 1996; Lane \& Brenckle, 2005; Vdovenko, 2001; Waters \& Condon, 2012). As a result, paradoxically, 
significant parts of the Serpukhovian are not included in studies dealing with the Serpukhovian, but using it as equivalent to the Pendleian and Arnsbergian regional substages for Western Europe (e.g., Brand, 2011; Sevastopulo, 2009).

Another conflicting point for a well-constrained calibration and correlation of the regional biozones/substages, is the definition of the stratotypes for the Serpukhovian substages. This did not follow a uniform criterion in terms of facies and fauna, being frequently based, unevenly, on deep-water versus shallow-water facies, or nektonic/pelagic versus benthic faunas, and hence of questionable national correlation, even moreso, for worldwide correlation.

The Serpukhovian Stage was originally defined by Nikitin (1890) in the Moscow Basin, and was divided into five substages: Tarusian, Steshevian, Protvian, Zapaltjubian and Voznesenskian. The lower three substages (Tarusian, Steshevian and Protvian) were defined in the Moscow Basin region (Shvetsov, 1932; Khimenkov, 1934), based on shallow-water platform facies. However, because of poor preservation or absence of the upper part of the Serpukhovian, the Zapaltjubian and Voznesenskian substages were defined elsewhere, in the Donbass Basin of Ukraine (Aizenverg et al., 1979). Subsequently, the Voznesenskian was considered as part of the Bashkirian (Nemirovskaya, 1987) and hence the lowest part of the Pennsylvanian.

In Britain, the stratigraphic interval inferred to be laterally equivalent to the Serpukhovian, is approximately composed of the Brigantian (upper part), Pendleian, Arnsbergian and basal Chokierian substages. The Brigantian Substage was proposed by George et al. (1976) in shallow-water facies from the Stainmore Trough; in Belgium it corresponds to the upper part of the Warnantian (Poty \& Hance, 2006). The Pendleian was defined by Ramsbottom (1981) at Light Clough, Pendle Hill, in deep-water facies of the Craven Basin, whereas the Arnsbergian was proposed by Rambottom (1969) in Arnsberg (Westphalia, Germany), also in deep-water facies (with a representative parastratotype for Britain and Ireland in Stony River, County Leitrim, Ireland). The Pendleian and Arnsbergian are widely recognized substages for Western Europe zonations (see Davydov et al., 2012). Correlation between shallow-water and deepwater facies in Britain is mostly based on ammonoids, although the occurrence of this 
fossil group north of the Craven Basin (in the shallow-water platform successions of the Askrigg and Alston blocks) is rather scarce (Waters \& Condon, 2012). This uneven facies distribution and use of different fossil groups for the recognition of these substages, leads to conflicting data between deep- and shallow-water facies in some periods, a feature highlighted by Cózar and Somerville $(2014,2016)$ for northern England, and subsequently, correlations and comparisons with the international zonal schemes can induce significant errors (Cózar \& Somerville, 2014).

The aims of this study are firstly, the revision of middle and upper Mississippian rocks in Ireland (including both the Republic of Ireland and Northern Ireland) which could be correlated with the Serpukhovian stage (Figure 1). These rocks were previously assigned to the regional substages in England (Brigantian, Pendleian and Arnsbergian) and thus, of a low value for international correlation. The second aim, is the revision of faunal assemblages and inclusion of new foraminiferal data, to help date sections more precisely, and to enable biostratigraphic correlations to be made with upper Viséan-Serpukhovian successions in northern England.

\section{CRITERIA FOR THE DEFINITION OF THE SERPUKHOVIAN STAGE AND SUBSTAGES IN IRELAND}

The base of the Serpukhovian Stage adopted here, in principle, is the FAD of the conodont Lochriea ziegleri. This taxon is rarely documented in Britain and Ireland, and it is first recorded from the Middle Limestone of the Askrigg Block in northern England (Varker in Skompski et al., 1995), and in the Magowna Formation in the

Kilnamona/Magowna and St Brendan's Well sections in south central Ireland (Barham et al., 2015; Meischner in Skompski et al., 1995) and Lugasnaghta stream section in Northern Ireland (Sevastopulo \& Barham, 2014; Barham et al., 2015). In sections from Ireland, the FAD of L. ziegleri is clearly younger than in Britain, and in sections in south central Ireland, it even occurs in the same beds as those containing the ammonoid Cravenoceras leion of the $\mathrm{E}_{1}$ zone (Hodson \& Lewarne, 1961). 
The data from the sections in northern England were also revised in Sevastopulo and Barham (2014), and those authors confirmed that the FAD of L. ziegleri is from "the lower part of the Middle Limestone". The Middle Limestone is a composite carbonate unit in the Askrigg Block of northern England, which represents the amalgamation of the Single Post, Cockleshell and Scar limestones, known from the Stainmore Trough, Alston Block and Northumberland Trough farther to the north (Holliday, Burgess, \& Frost, 1975; Rose \& Dunham, 1977). Thus, Sevastopulo and Barham (2014) interpreted that the FAD of $L$. ziegleri should be correlated with levels equivalent to the Single Post Limestone, assigned by Ramsbottom (1974) to the $\mathrm{P}_{1 \mathrm{~d}}$ ammonoid subzone, but according to the revised ammonoid zones in Korn and Titus (2011), this level should be considered as the $P_{1 c}$ subzone (see details in Sevastopulo \& Barham, 2014). However, it is worth highlighting that (i) the FAD of L. ziegleri in the Single Post Limestone is based on an imprecise "lower part", because the Middle Limestone can be subdivided into the three limestone units observed further to the north; (ii) the FAD of L. ziegleri in the Single Post Limestone is based on an indirect correlation, because the stratigraphic details of the section(s) were never published; (iii) the assignment to the $\mathrm{P}_{1 \mathrm{~d}}$ subzone is based on an indirect correlation, assuming ammonoids recorded further to the north in England, but not present in the Askrigg Block; and (iv) the reinterpretation of the $\mathrm{P}_{1 \mathrm{c}}$ subzone is equally based on an indirect correlation of the ammonoid zone by comparison with ammonoids in the basins in Germany.

The separation of the Single Post, Cockleshell and Scar limestones is more easily recognisable in the Alston Block and Stainmore Trough, but further south they become thinner, and eventually are amalgamated as one limestone unit in the Askrigg Block. Nevertheless, thin shale partings can be used to distinguish the three individual limestones within the amalgamated Middle Limestone (e.g., Dunham, 1990; Rose \& Dunham, 1977; Strank, 1981). The extreme amalgamation is observed in the Pateley Bridge region, included as part of the southern Askrigg Block succession, and situated between the North and Middle Craven Faults. There, the so-called Toft Gate Limestone, is the lateral equivalent of the combined Simonstone, Single Post, Cockleshell and Scar limestones (Dunham \& Stubblefield, 1945). Thus, if the limestones equivalent within the Middle Limestone are not well established, and the FAD of 
Lochriea ziegleri is not precisely located, to assume that this taxon first occurs in the Single Post Limestone needs further supporting evidence. Therefore, the first point to clarify is, if the FAD of L. ziegleri in any given section corresponds to the Single Post Limestone, it should be desirable to demonstrate the same event in sections north of the Askrigg Block, where limestones are much more clearly separated by thick clastic intervals. On the other hand, considering the stratigraphical reinterpretation of the ammonoids above the Single Post Limestone as typical of the $\mathrm{P}_{1 \mathrm{c}}$ subzone, it is not clear if that means that the $\mathrm{P}_{1 \mathrm{~d}}$ subzone of $\mathrm{N}$ England does not exist, or if the ammonoids are not representative of the $\mathrm{P}_{1 \mathrm{~d}}$ subzone of England (because this zone is recognized from shales above the Hardraw Limestone), or if the $\mathrm{P}_{1 \mathrm{~d}}$ subzone should be restricted to shales between the Cockleshell and Scar limestones.

Apart from conodonts and ammonoids, Hallett (1971) and Strank (1981) studied the foraminifers of the Middle Limestone and Single Post/Cockleshell/Scar limestones. Subsequent studies of those limestones have shown them to be barren or with very limited foraminiferal assemblages (e.g., Cózar \& Somerville, 2004; Johnson, Somerville, Tucker, \& Cózar, 2011). The Scar Limestone and younger limestone beds were studied in detail by Cózar and Somerville (2016).

Unfortunately, Hallett (1971) did not distinguish the three individual limestone units which comprise the Middle Limestone, and thus he considered it as a single unit. The only relevant foraminifer first occurring from the Middle Limestone is Neoarchaediscus gregorii, although the specimen he illustrated (Hallet, 1971, pl. 5, fig. 12) is from the Three Yard Limestone, and is considered herein as Planospirodiscus aff. taimyricus (in contrast to the nomimal species, this form contains some inner skew-coiled whorls). Thus, it is not clear what was the diagnosis used by Hallett (1971) in identifying $N$. gregorii.

Strank (1981) studied these limestones at Birkett Cutting (Askrigg Block), Whitfield Gill (Askrigg Block) and Trout Beck (Alston Block). The main foraminiferal features for this interval were the reduction in the number of large Archaediscus at angulatus stage (cf. Conil, Longerstaey, \& Ramsbottom, 1980; Pirlet \& Conil, 1977), and an increase in the number of small asteroarchaediscinae, including the first occurrence of 
Asteroarchaediscus bashkiricus and $A$. rugosus. These features are noted from the Single Post Limestone, but they are more accentuated in the Cockleshell Limestone. These foraminiferal characteristics also coincide with a major change in the coral and brachiopod fauna between the Single Post and Cockleshell limestones, which led Strank (1981) to propose that the base of the late Brigantian $\mathrm{P}_{2}$ zone should be located at the base of the Cockleshell Limestone. Furthermore, at Birkett Cutting, "Millerella" tortula occurs in the Cockleshell Limestone (Strank, 1981, pl. 73, fig. 24, as cf. Planoendothyra sp.), and at Whitfield Gill, it is noteworthy for the first occurrence of Neoarchaediscus gregorii from the Single Post Limestone. With the available data, the occurrence of $N$. gregorii from levels of the uppermost early Brigantian might be the best candidate in the British Isles to recognize horizons that might be equivalent to the FAD of Lochriea ziegleri, although further studies focused on the Single Post and Cockleshell limestones are needed to increase the knowledge of their foraminiferal assemblages. Neoarchaediscus gregorii, together with clearer basal Serpukhovian (Tarusian) markers, such as Neoarchaediscus postrugosus and "Millerella" tortula are recorded from the Scar Limestone (Cózar \& Somerville, 2016), whereas, as mentioned above, "M." tortula has been recorded from the Cockleshell Limestone. However, the first occurrence of those taxa can show important delays in Britain. For instance, the best Serpukhovian foraminiferal marker, N. postrugosus, is first recorded in the Midland Valley of Scotland from younger levels, correlated with the Three Yard Limestone of northern England (Cózar, Somerville, \& Burgess, 2010). "Millerella" tortula is, so far, unknown in the Midland Valley, whereas $N$. gregorii is recorded from the levels immediately below the Lower Limestone Formation (late Brigantian to Pendleian) in limestones at Kirkcaldy and Catcraig (East Fife and East Lothian, respectively) (Karbub, 1993), which have been correlated with the Single Post Limestone (Cózar \& Somerville, in press). Well-constrained regional markers of the Single Post Limestone or equivalent levels are Asteroarchaediscus bashkiricus and $A$. rugosus, although more simple and small forms, such as Asteroarchaediscus pustulus has been recorded from the top of the Tynebottom Limestone (Cózar \& Somerville, 2004). 
Younger Serpukhovian substages are recognized on the basis of the foraminifers recorded in the Alston Block and Stainmore Trough, as described in Cózar and Somerville $(2014,2016)$, and their associated ammonoid/miospore biozones. Thus, levels correlated with the Steshevian Substage include the following main limestones: Three Yard Limestone (oldest), Four Fathom Limestone, Great Limestone and Little Limestone (Figure 2). The main criteria for this correlation are the occurrence of Eostaffellina from the Three Yard Limestone and Eosigmoilina/Brenckleina from the Four Fathom Limestone, although the Three Yard Limestone might be considered also as part of the Tarusian. The Protvian Substage was restricted to the Crag Limestone, due to the first occurrence of large and rounded Eostaffellina, such as Eostaffellina protvaeensis, new name proposed by Gibshman (2019) for E. protvae. The Zapaltjubian might be present from the Rookhope Shell Band, Lower Fell Top Limestone and Coalcleugh Limestone, based on the occurrence of common Plectostaffella, including Plectostaffella varvariensis and P. jakhensis. However, classical markers of the Zapaltjubian (Loeblichia minima, Monotaxinoides transitorius and Seminovella elegantula) do not occur up to the Botany/Grindstone Limestone. Cózar and Somerville (2014) suggested that the possible level of correlation with the Voznesenskian (Bashkirian) was the Botany/Grindstone Limestone. However, Cózar and Somerville (2016) recorded the possible occurrence of Plectostaffella bogdanovkensis and Eostaffellina? sp. A from the Upper Fell Top Limestone. This species of Plectostaffella is mostly restricted to the Bashkirian and the plausible species of Eostaffellina has differentiated layers in the wall, a feature typical of Pseudostaffella and Varistaffella, both genera restricted to the Bashkirian (see discussion in Cózar \& Somerville, 2016). Both taxa suggested that the possible level of correlation with the Voznesenskian is the Upper Fell Top Limestone (Figure 2). However, the conodont Declinognathodus noduliferus, the marker for base of the Bashkirian, has been only recorded from the $\mathrm{H}_{1 \mathrm{a} 2}$ subzone of the Chokierian Substage in Stonehead Beck section (Riley, Varker, Owens, Higgins, \& Ramsbottom, 1987; Varker, 1994). This upper part of the succession in Britain and Ireland needs to be further investigated.

For the correlation with the ammonoid and miospore zones, the biozones of those fossil groups recognized in the Alston Block are adopted here, based on data in Owens, 
McLean and Bodman (2004), Brand (2011), Waters, Somerville, Stephenson, Cleal, and Long (2011), Waters, Millward, and Thomas (2014), and McLean, Owens, Bodman, and McLean (2018). As mentioned above, many shaley facies in the upper part of the studied succession could be only dated using miospore zones, and hence, there is an important issue concerning the correlation of the base of the NC zone. For some authors, the base of this zone should be correlated with the $\mathrm{P}_{2 b}$ ammonoid subzone (e.g., George et al., 1976; Owens et al., 2004; Waters et al., 2011), whereas for others, it should be correlated with intermediate levels of the $\mathrm{P}_{1 \mathrm{a}}$ subzone (Sevastopulo \& Wyse Jackson, 2009), or its base should be correlated with the base of the $\mathrm{P}_{2 a}$ subzone (McLean et al., 2018). Miospore details in Owens et al. (2004) and Owens, McLean, Simpson, Shell, and Robinson (2005) suggest that the NC zone occurs in shales associated with the St Monans Little Limestone and Second Abden Limestone in Fife, Scotland and the Five Yard Limestone in northern England, and thus, the correlation with the $\mathrm{P}_{2 b}$ zone is followed here (Figure 2).

\subsection{Faunal constraints for the Irish Mississippian zonation and correlation}

A significant problem to acknowledge is the particularities of the fauna in Ireland, in that some foraminiferal taxa do not show, apparently, the same stratigraphic range as in northern England.

The best foraminifer to recognize the Single Post Limestone in northern England is Asteroarchaediscus, but in Ireland, its first occurrence is located in basal levels of the Brigantian (Cózar \& Somerville, 2005; Cózar, Somerville, \& Somerville, 2005a; Cózar, Somerville, Aretz, \& Herbig, 2005b; Cózar, Somerville, Mitchell, \& Medina-Varea, 2006; Somerville \& Cózar, 2005), or even from the latest Asbian (Jones \& Somerville, 1996). The first occurrence of Neoarchaediscus gregorii is also a problematic taxon, because in rare cases, it is present within the early Brigantian (Cózar \& Somerville, 2005), although, generally, it is associated to levels recognized as close to the base of the late Brigantian (e.g., Cózar et al., 2006). Within the continuous carbonate successions in 
Ireland, archaediscids show a three-stage evolution. In the first stage, Neoarchaediscus gregorii first occurs, together with primitive forms, assigned to the genus Planospirodiscus (Figure 3a-b, 3f, 3h-I). In the second stage, Neoarchaediscus postrugosus first occurs, although those specimens are more similar to the paratype defined by Reitlinger (1949), with a more compact shape, and less evolute final whorl (Figure 3j-m). In addition, evolved forms of Planospirodiscus co-occur with the latter (e.g. Planospirodiscus aff. taimyricus). In the final stage, Neoarchaediscus postrugosus, similar to the holotype first occurs, marked by a narrower test, and more clearly evolute final whorl (Figure 3n-o). In this higher level, more evolved Planospirodiscus taimyricus and Tubispirodiscus are also recorded, together with "Millerella" tortula. The two morphotypes of $N$. postrugosus are distinguished, herein, as form 1 (for the paratype) and form 2 (for the holotype). The difference between both types of the species was discussed by Cózar and Somerville (2016), although the species recorded from the base of the Scar Limestone in northern England, contain both morphotypes from the base. Taking into consideration the poverty in foraminiferal data from the Single Post and Cockleshell limestones, it is plausible, that at least, form 1 should occur in those horizons (or perhaps even both). Further detailed foraminiferal research is necessary in the Single Post and Cockleshell limestones to confirm the first occurrences of those taxa compared to the first occurrence of Lochriea ziegleri. In contrast to Kulagina (2017), Neoarchaediscus gregorii is considered, herein, to be derived from other discoidal primitive forms, such as N. incertus (= N. probatus; Brenckle \& Grelecki, 1993), with more open whorls in the lumen. The progressive occlusion of the lumen as well as incipient development of evolute final whorls in $N$. postrugosus, seems to be culminated with more evolute final whorls in specimens such as $N$. shugorensis, completing a phylogenetic lineage. This lineage is characterized by an aligned arrangement of the final whorls. On the other hand, Asteroarchaediscus seems to be derived from wider species of Neoarchaediscus, also with a progressive occlusion of the lumen, such as $N$. parvus. The holotype of $N$. parvus shows oscillating coiling (see reillustration of the types in Kulagina, 2017), however, one of the paratypes described by Rauser-Chernousova (1948) shows an aligned coiling (it looks like N. shugorensis), a fact that led some authors to consider the species as being characterized by an aligned coiling (e.g., Vachard, 1988). 
Owing to its occlusion, $N$. postrugosus has been considered as Asteroarchaediscus by some authors (e.g., Vachard, 1988; Brenckle \& Grelecki, 1993). However, to accept this genus identification for the species, that would imply that Asteroarchaediscus is a polyphyletic genus, when really, a clear independent lineage can be recognized for the discoidal forms. On the other hand, Brenckle, Ramsbottom, and Marchant (1987) and Brenckle and Grelecki (1993) considered Planospirodiscus as a senior synonym of Tubispirodiscus, because they interpreted that there is no occlusion of the lumen in the types of Planospirodiscus (interpreted as cements). However, occluded and nonoccluded forms with more or less parallel flanks occur readily in the geological records (e.g. Cózar \& Somerville, 2013), and thus, both genera are considered valid (Vachard, 1988).

The conodonts Lochriea nodosa and L. mononodosa were considered to be restricted to the late Brigantian in Ireland (Aldridge, Austin, \& Husri, 1968; Austin, Conil, \& Husri, 1970; Austin \& Husri, 1974; Somerville, 1999), and both species have been widely used as markers for this substage. In fact, this stratigraphic record was rather similar to that in England (e.g., Bowden, 2001; Metcalfe, 1981), although Varker (1964), Davies, Austin and Moore (1993) and Varker in Skompski et al. (1995) recorded these species from the Gayle Limestone in the Askrigg Block. In Ireland, all the records of these species seems to be restricted to the late Brigantian, except in the Cuilcagh Mountains, where Kelly (1989) recorded L. nodosa from the Meenymore Formation in the Aghagrania River section (Table 1), which is considered here as early Brigantian (see Cózar et al., 2006; Figure 2).

The ammonoid records in the lower part of the studied successions from Ireland are very limited, due to a higher predominance of shallow-water platform carbonates. Thus, data on ammonoids are rather sparse, except for the successions in northwest Ireland, where thin limestones are interbedded with thicker shales (e.g., Brandon, 1972, 1977; Brandon \& Hodson, 1984; Hodson \& Moore, 1959; Korn, 1990; Moore, 1958). However, even there, there is an apparent conflict between the ammonoids and the foraminiferal and conodont distributions (compare Barham et al., 2015; Cózar et al., 2006; Kelly, 1989; Sevastopulo \& Barham, 2014). Ammonoids in the shales in the 
upper part of the studied successions are relatively common (Ramsbottom et al., 1978).

\section{SERPUKHOVIAN IN IRELAND}

The upper Viséan-Serpukhovian rocks in Ireland occur in six major basins/regions: South Munster Basin, North Munster Shelf, Shannon Basin, Dublin Basin, NW Carboniferous Basin, and Northern Ireland (similar to those documented in Waters et al., 2011), which will be described in geographical sequence, from south to north (Figures 1, 2).

\subsection{South Munster Basin}

In the South Munster Basin, the macrofauna of the Lispatrick Formation suggests a Brigantian age (Sleeman \& Pracht, 1994), from the lower levels (Figure 2), based on the occurrence of the bivalve Posidonia becheri. Ammonoids recorded from the middle part of the formation in Old Head were assigned to the $\mathrm{P}_{1 \mathrm{~d}}$ goniatite subzone, whereas Eumorphoceras (not identified at species level, and thus, only suggesting a Pendleian or Arnsbergian age) was recorded $3 \mathrm{~m}$ above the base of the White Strand Formation (Naylor, Sevastopulo, \& Sleeman, 1985). In Galley Head, goniatites of the $\mathrm{P}_{1 b}-\mathrm{P}_{1 c}$ subzones were recorded (Graham, 1975), and Naylor et al. (1985) reported ammonoids of the $P_{1 c}$ subzone, $6 \mathrm{~m}$ above the base of the Lispatrick Formation, and approximately $18 \mathrm{~m}$ higher up, ammonoids of the $\mathrm{P}_{2 \mathrm{a}}$ subzone. Sevastopulo and Wyse Jackson (2009) first proposed a Serpukhovian age for the uppermost 10 metres of the Lispatrick Formation, although they only considered as plausible, Serpukhovian rocks of the $\mathrm{P}_{2}$ zone. Assuming the previously discussed equivalence of the ammonoid subzones is correct, at least the upper half of the Lispatrick Formation corresponds to the Serpukhovian. Owing to a predominance of mudrocks and the rarity of ammonoids for a precise subdivision, and taking into consideration the thicknesses of each interval, 
it seems that strata equivalent to the Tarusian Substage might be complete, but younger rocks might be absent, or extremely condensed, due to the thinner occurrence of rocks above the well-constrained Tarusian assemblages (Figure 2). The White Strand Formation is supposed to range from the Pendleian to the Chokierian (Sleeman \& Pracht, 1994), although as mentioned above, the datings are of low resolution, because the Eumorphoceras ammonoid did not allow a more precise dating (Naylor et al., 1985), and the succession can be eroded in some sections, as in Old Head, and at Seven Heads (Naylor, Higgs, Reilly, \& Sevastopulo, 1988). Miospores recorded by Naylor et al. (1988) from the base of the lower member belong to the NC miospore zone and the upper part to the Arnsbergian TK biozone (Naylor et al., 1988) (Figure 2). Similarly, Somerville, Jones, and Philcox (1996a) also reported the NC miospore zone from the base of the formation in the Cloyne Syncline. These data led Sevastopulo (2009) and Waters and Somerville (2011) to consider that the White Strand Formation extends from the base of the Pendleian up to the Bashkirian, although the miospore zone from the base of the formation might be restricted to late Serpukhovian, or Pendleian $\mathrm{E}_{1 \mathrm{c}}$ subzone (Figure 2). In Whiddy Island, there are also record of shales, where the East Point Member of the Reenydonagan Formation contain ammonoids of the $E_{2 b}$ subzone (Naylor, Jones, \& Clayton, 1978), and higher up, the Middle Battery and Kilmore formations are supposed to contain higher levels of the Arnsbergian to Chokierian, although they are not dated (Sevastopulo, 2009) (Figure 2). Compared to sections in Seven Heads, it might be suggested that the lower part of the Reenydonagan Formation ranges down to similar levels as the White Strand Formation. However, all the above-mentioned outcrops were included within the Kinsale sub-basin of Naylor, Sevastopulo, and Sleeman (1989), whereas Whiddy Island belongs to the Bantry sub-basin (Figure 2). It is difficult to extrapolate between both sub-basins, since they both had strong differences from the Lower Viséan (Arundian) upwards (Sevastopulo \& Wyse Jackson, 2009). In both shaley successions of the Kinsale and Bantry sub-basins, further work is required to precisely date the lower extension of the formations, as well as to confirm a rather plausible hiatus in part of the early Serpukhovian. 


\subsection{North Munster Shelf/South Central Ireland}

In the Buttevant area of north County Cork, the Liscarroll Limestone Formation was attributed to the Brigantian (Gallagher, 1992, 1996; Gallagher \& Somerville, 1997), and Somerville, Waters, and Collinson (2011) considered the Liscarroll Limestone Formation extending from the early Brigantian to the $\mathrm{P}_{2 a}$ subzone, and thus, supposedly late Brigantian. Rugose corals recorded in this formation were assigned to the H zone (sensu Mitchell, 1989), representative of the early Brigantian (see Gallagher \& Somerville, 1997). Foraminifers of the formation are typically early Brigantian (see Gallagher, 1996; Gallagher \& Somerville, 1997), and the most evolved forms are those of Loeblichia paraammonoides and Howchinia trans. Monotaxinoides. Loeblichia paraammonoides is first recorded from the Gayle Limestone (Askrigg Block) in northern England, in the foraminiferal assemblage 5 of Cózar \& Somerville (2004), of early Brigantian age. The so-called Howchinia trans. Monotaxinoides is reinterpreted herein as Hemidiscopsis declivis, a taxon described from the late Viséan in Russia (Mikhailovian Substage; Cózar, Sanz-López, \& Blanco-Ferrera, 2015; Ganelina, 1956). However, the only other occurrence of this taxon in Ireland has been reported from the upper part of the Clogrenan Formation in County Carlow (see below) (Somerville \& Cózar, 2005, as cf. 'Monotaxinoides' sp.) in upper Brigantian rocks. It is necessary to note here, that Gallagher (1996) and Gallagher and Somerville (1997) correlated the upper part of the Liscarrol Limestone Formation with the upper part of the Clogrenan Formation (corresponding to the Serpukhovian) (see below). Nevertheless, the rapid lateral facies changes of the Clogrenan Formation (see Cózar \& Somerville, 2005), does not allow to confirm that similar facies between the upper member of the Liscarroll Limestone Formation and the Clogrenan Formation are coeval. Thus, there is no clear evidence of the presence of the Serpukhovian in the Liscarroll Limestone Formation, and the succession is probably restricted to the upper Viséan (Figure 2).

In east County Limerick, the Dromkeen Limestone Formation is, in part, the lateral equivalent of the Liscarroll Limestone and Clogrenan formations, which also extends from the early Brigantian up to the late Brigantian $P_{2 a}$ subzone (Somerville et al., 2011). 
The attribution to the younger subzone is based on the finding of a single element of the conodont Lochriea mononodosa (Somerville, Strogen, \& Jones, 1992). In previous publications, the occurrences of L. nodosa or L. mononodosa were considered as guides for the late Brigantian (e.g., Austin et al., 1970; Austin, 1973; Jones \& Somerville, 1996; Somerville, 1999). However, as discussed previously, in England, these species occur in intermediate positions of the early Brigantian, and thus, the restriction of both species to the late Brigantian is usually the rule, but some exceptions exist in England and Ireland. Rugose corals and foraminifers from the Dromkeen Limestone Formation do not suggest the occurrence of the late Brigantian. Thus, the Dromkeen Limestone Formation, like the Liscarroll Limestone Formation, probably does not extend to basal levels of the Serpukhovian stage (Figure 2).

The Liscarroll Limestone Formation passes northeastwards, to Counties Kilkenny and Carlow, where it is called the Clogrenan Formation (Archer, Sleeman, \& Smith, 1996; Tietzch-Tyler \& Sleeman, 1994; Figure 2). The lower part of the Clogrenan Formation is well exposed in several quarries in the eastern flank of the Castlecommer Syncline, as at Clogrenan Quarry, whereas the upper part of the formation is more complete in the northern part of the region, in County Laois, such as in Guileen-1 Borehole and Dunamase Quarry (Table 1). The Clogrenan Formation ranges through the early and late Brigantian (Cózar \& Somerville, 2005). The late Brigantian age was recognized by the co-occurrence of Janischewskina typica and Endothyranopsis sphaerica. These taxa are typically recorded from the Five Yard Limestone from northern England in foraminiferal assemblage 7 (Cózar \& Somerville, 2004). On the other hand, the early Brigantian interval was subdivided in three units (3-5) by Somerville and Cózar (2005). In the middle part of the unit 3, is the FAD of Neoarchaediscus gregorii, with Neoarchaediscus postrugosus form 1, a few metres above (Figure 3). These horizons are interpreted here as equivalent to the Single Post-Cockleshell limestones in England, and thus considered to mark the base of the Serpukhovian, laterally equivalent to the Tarusian. The upper part of unit 3 contains the FAD of Planospirodiscus taimyricus, $P$. minimus and rare Climacammina. In unit 4 are recorded the FAD of Neoarchaediscus postrugosus form 2 and "Millerella" tortula (as Millerella? sp.). This horizon of unit 4 is correlated with the Scar Limestone Member of northern England, whereas the upper 
part of the Clogrenan Formation (units 5 and 6 ) is considered equivalent to the Five Yard Limestone Member (Figure 4). Younger Serpukhovian strata in the region are composed of the Luggacurren Shale Formation, which disconformably overlies the Clogrenan Formation, has been dated as Arnsbergian ( $\left.E_{2 c}\right)$. However, the basal levels, comprise cherts and black shales (Coonbeg Chert and Glenview Shale members, respectively) that could not be dated. Higgs (1986) assigned the Coonbeg Chert to the Arnsbergian $E_{2 b}$ subzone due to the lithological similarities with cherts in County Limerick. Sevastopulo (2009) and Somerville et al. (2011) interpreted these cherts as belonging to the $E_{2 b}$ subzone.

In south County Wexford, the Viséan carbonate succession recorded from boreholes was revised by Nagy et al. (2005). The youngest strata of the Wexford Formation are of late Asbian age. Clayton, Sevastopulo, and Sleeman (1986) attributed the Park Formation, which unconformably overlies the Asbian strata, to the Namurian ( $E_{1 c}$ to $R_{2 c}$ subzones), which Somerville et al. (2011) interpreted as Pendleian to Marsdenian. However, there is no biostratigraphic dating from this mudstone formation.

\subsection{Shannon Basin}

In northwest County Limerick, close to Foynes, there is a deep-water succession that extends through the Brigantian into the Pendleian (Parsonage, Corgrig Lodge and Clare Shale formations; Figure 2). The upper 10 metres of the Parsonage Formation contain calcilutite wackestone with rare thin grainstones, which contain Brigantian foraminifers (Sleeman \& Pracht, 1999). Late Asbian conodonts were recorded through the formation, and thus, the formation is interpreted not to reach the Serpukhovian. The overlying Corgrig Lodge Formation contains conodonts of the Lochriea nodosa Zone, at $15 \mathrm{~m}$ above the base of the formation, which was considered as late Brigantian in Sleeman and Pracht (1999), Somerville et al. (2011) and Somerville (2016a). Ammonoids of this formation are only representative of the $B_{2}$ subzone (Hodson \& Lewarne, 1961), but productid brachiopods and foraminiferal assemblages 
recorded by Shephard-Thorn (1963) were attributed to the upper D2 zone or equated with the V3c foraminiferal zone of Belgium (= Brigantian). Waters et al. (2011) extended the formation from the early Brigantian to the lower part of the late Brigantian. Sevastopulo and Wyse Jackson (2009) only considered the Clare Shale Formation as Serpukhovian. Assuming, as previously stated, that the first occurrence of Lochriea nodosa in Ireland is usually at levels within the $\mathrm{P}_{2}$ zone (although, exceptionally, it has been recorded from the $\mathrm{P}_{1}$ zone), the Corgrig Lodge Formation is considered here (at least in part) as the lower part of the early Serpukhovian (Figure 2). Shephard-Thorn (1963) inferred a plausible break in the deposition, involving parts of the $\mathrm{D} 2$ zone, $\mathrm{P}_{2}$ and $\mathrm{E}_{1}$ zones in some areas, because in the southern Foynes area, the first ammonoids in the Clare Shale Formation were assigned to the $E_{2}$ zone. Nevertheless, this formation further to the west contains ammonoids of the $E_{1}$ zone (Hodson \& Lewarne, 1961; Sevastopulo, 2009; Wignall \& Best, 2000; Wignall, Somerville, \& Braithwaite, 2016), although the basal $E_{1 a}$ subzone is not present, which confirms the hiatus between the Viséan limestones and the Namurian shales. This hiatus suggests that the Viséan limestones could not reach the late Brigantian in the region, because all the foraminiferal/ammonoid/conodont markers suggest an age compatible with the $\mathrm{P}_{1}$ zone passing into the $\mathrm{E}_{1 \mathrm{~b}}$ subzone. This also confirms that the late Serpukhovian is present, but only represented as shales (Figure 2). However, Sleeman and Pracht (1999) and Sevastopulo (2009) considered that the Clare Shales Formation is in continuity with the underlying limestone in some regions, although palaeontological evidences were not provided for each locality.

In the southwestern part of the Shannon Basin, at Ballybunnion, $40 \mathrm{~km}$ west of Foynes (Figure 1), the formations are the same as those described above, although this area is less-well dated than the Foynes region, but the formations do not seem to be synchronous. The only available dating of the Corgrig Lodge Formation records ammonoids of the $\mathrm{P}_{1 \mathrm{~d}}$ zone in the upper part of the Formation (Sleeman \& Pracht, 1999). In the Clare Shale Formation, Kelk (1960) recorded ammonoids of the $P_{2}$ zone from the lower levels of the formation (up to $\mathrm{H}_{1}$ Chokierian). Thus, in this region, the succession appears to be continuous, and the base of the Clare Shale Formation seems to be older than in the Foynes area. This difference in age within the Shannon Basin 
was already recognised by Hodson and Lewarne (1961). More recent works in the region did not investigate in detail this diachronism (e.g. Wignall et al., 2016) or they focused their research on the youngest beds of the Clare Shale Formation (e.g., Braithwaite, 1993, 1995; Fallon \& Murray, 2015).

In the Burren region, north County Clare, forming the southern part of the GalwayRoscommon Shelf (Pracht \& Somerville, 2015; Sevastopulo \& Wyse Jackson, 2009), are recorded the upper Viséan shallow-water carbonate platform facies of the Shannon Basin. This comprises the Burren Formation (Asbian) and overlying Slievenaglasha Formation (Figure 2). The latter extends throughout the Brigantian, although only the uppermost part of the formation, the Lissylisheen Member, was previously considered as late Brigantian (Gallagher, 1996; Gallagher, MacDermot, Somerville, Pracht, \& Sleeman, 2006). This was due to these authors recording a foraminifer identified by them as "close to Archaediscus at tenuis stage", which is likely, a transitional form between the angulatus and tenuis stages (cf. Conil, Longerstaey, \& Ramsbottom 1980; Pirlet \& Conil, 1977) or an evolutus stage (cf. Vachard, 1988) or angulatus-tenuis stage (cf. Zandkarimi, Vachard, Najafian, Hamdi, \& Mosaddegh, 2017). Furthermore, Clarke (1966) described the rugose coral Orionastraea from the top of the formation in Lisdoonvarna, which is representative of the late Brigantian coral zone J of Mitchell (1989), although revision of the genus in Ireland by Nudds (1979) restricted it to the $\mathrm{P}_{1 \mathrm{~d}}$ subzone. Succeeding the Slievenaglasha Formation, in stratigraphic continuity, is the Magowna Formation, which records the transition into the Pendleian (Sleeman \& Pracht, 1999), with ammonoids of the $E_{1}$ zone. Thus, it seems that much of the Serpukhovian is well represented in this region. Meischner (in Skompski et al., 1995) recorded common conodont assemblages from the Kilnamona Stream section, including Lochriea commuta, L. mononodosa, L. cruciformis, L. ziegleri and L. senckenbergica. The same beds were also studied by Barham et al. (2015), and they also found similar rich conodont assemblages. However, none of them sampled the thick massive limestone of the Slievenaglasha Formation, except for the top bed, from which similar assemblages were recorded, which implies that the first occurrence of these conodonts has to be at a lower level in this formation. 
The Ballyelly Member [the third member (of 4 members), in the upper part of the Slievenaglasha Formation, Gallagher et al., 2006; Figures 2, 4] has been resampled in the $\mathrm{N} 67$ roadside quarry, $3 \mathrm{~km}$ northeast of the town of Lisdoonvarna. This 6-m-thick section, near the base of the member, contained the following foraminifers: Archaediscus at angulatus stage (common), A. chernoussovensis, Asteroarchaediscus bashkiricus (common), A. rugosus, Endothyra spira, Howchinia bradyana (common), $H$. gibba (common), Janischewskina? sp., "Millerella" tortula, Neoarchaediscus gregorii (common), N. karreriformis, N. occlusus, N. parvus (common), N. postrugosus forms 1 and 2, N. spp. (common), Omphalotis minima, Pseudoammodiscus spp., Pseudolituotuba gravata, Pseudotaxis eominima, Tetrataxis spp. (common), Tubispirodiscus sp. and Valvulinella youngi (common) (Figure 5). This rich assemblage allows us to assign the Ballyelly Member to the early Serpukhovian, since it contains markers of the Tarusian Substage. The occurrence of both forms of N. postrugosus, at $1 \mathrm{~m}$ above the base of the quarry, suggest that the likely base of the Serpukhovian is located in slightly older levels than the base of the member, i.e. within the top of the underlying Fahee North Member (Figures 2, 4).

The uppermost part of the Slievenaglasha Formation (the Lissylisheen Member, only 2 $\mathrm{m}$ thick) has been sampled in the Gowlaun River section in Lisdoonvarna (see Somerville, 2016b, fig 5.2.11), and Vigo Cave and Vigo Pothole (Kilfenora). They contain the foraminifers: Archaediscus at angulatus stage (common), $A$. at angulatus stage transitional to tenuis stage (common), $A$. at tenuis stage, Asteroarchaediscus bashkiricus (common), A. rugosus, Cepekia cepeki, Eosigmoilina cf. robertsoni, Howchinia gibba, Neoarchaediscus gregorii (common), N. postrugosus form 2, N. shugorensis, N. spp. (common), Planospirodiscus sp., P. taimyricus (common), Tetrataxis spp., Tubispirodiscus cornuspiroides (a species included in Tubispirodiscus as discussed in Cózar, Somerville, \& Burgess, 2008), T. simplissimus and T. spp. (Figure 6). This rich and diverse assemblage is representative of the Steshevian Substage, and correlatable with the Four Fathom Limestone in northern England (assemblage 9 in Cózar et al., 2010; Figure 4). Moreover, indirectly, the upper part of the Ballyelly Member is considered to include also the Three Yard Limestone (Figures 2, 4). 
The transition into the Pendleian of the Magowna Formation (about $3 \mathrm{~m}$ thick) has been sampled in Magowna Waterfall and the Kilnamona stream section, as well as from the upper metre of the Lissylisheen Member. The assemblages in the Magowna Formation are very similar to those from the Lissylisheen Member, with abundant Asteroarchaediscus, Planospirodiscus, discoidal Neoarchaediscus, Tubispirodiscus, and rare eosigmoilinids (Eosigmoilina robertsoni). However, in addition is recorded a different eosigmoilinid, Brenckleina cf. rugosa, and Brownediscus? (Figure 7). The latter taxon is a form very close to the nominal genus, although the inner whorls are not at tenuis stage. It is similar to specimens recorded in the Tramaka Encrinite of Belgium (Austin, Conil, Groessens, \& Pirlet, 1974; Brenckle, Ramsbottom, \& Marchant, 1987), of upper late Serpukhovian (Zapaltjubian Substage) age. The only comparable specimens in Britain were recorded from the Blae Pot Limestone of the Archerbeck Borehole in the Solway Basin (Scotland), a limestone correlated with the Little Limestone in northern England (Cózar \& Somerville, 2013), corresponding to the upper part of levels correlated with the Steshevian Substage (Figure 2). Thus, the assemblages are also assigned to the Steshevian Substage, and taking into consideration the occurrence of Cravenoceras leion in those beds, as well as Brownediscus?, it should be correlated with the Great Limestone of northern England (and the foraminiferal assemblage 10 in Cózar et al., 2010). No foraminiferal evidence of the late Serpukhovian has been recorded. The supposed lateral equivalence of the Magowna and Corgrig Lodge formations, as proposed by Sleeman and Pracht (1999), is not supported by the biostratigraphical data. Above the uppermost shales of the Magowna Formation, the succession is capped by the St Brendan's Well Phosphate Bed, which Wignall and Best (2000) and Wignall et al. (2016) considered to span the $E_{2 a 2}$ to $E_{2 c 2}$ interval. Thus, the late Serpukhovian (Protvian) corresponds to a hiatus (Figure 2), and the lower part of the phosphates and Clare Shale Formation represents the uppermost late Serpukhovian.

\subsection{Dublin Basin and Kingscourt Outlier}


In the Dublin Basin, deep-water basinal facies extend throughout the Viséan, which is flanked on the northern margins by shallow-water platform facies (Nolan, 1986;

Pickard, Jones, Rees, Somerville, \& Strogen, 1992; Pickard, Rees, Strogen, Somerville, \& Jones, 1994; Strogen, Somerville, Jones, \& Pickard, 1995; Strogen, Somerville, Pickard, Jones, \& Fleming, 1996). In the north County Dublin area at Loughshinny, Brigantian deep-water facies are represented by the Loughshinny Formation (Nolan, 1986; Pickard et al., 1994; Strogen et al., 1996). Precise foraminiferal data are documented in Nolan (1986), who recorded primitive Planospirodiscus from the lower part of the Loughshinny Formation, suggesting an uppermost early Brigantian age. Also, evolved Planospirodiscus taimyricus were recorded from the Ballustree Member (as gen. nov., Nolan, 1986, pl. 14, figs. 17-18), and Howchinia cf. subconica from the upper $4^{\text {th }}$ member. In addition, Brenckleina might be also present from the upper member (recorded by Nolan, 1986, pl. 16, fig. 28, as Asteroarchaediscus sp.). Pickard et al. (1992) recorded Lochriea mononodosa from intermediate positions in the formation. These taxa suggest that the Ballustree Member should be considered as equivalent to the Tarusian in age, and the Member 4 might correspond to the lower part of the Steshevian (Figure 2). The succeeding Donore Shale Formation contains Cravenoceras leion (Nevill, 1957), representing the upper part of the Steshevian. There are no biostratigraphical data from the overlying Balrickard Sandstone Formation, whereas the succeeding Walshestown Shale Formation contains ammonoids of the $E_{1 c}$ to $E_{2 b}$ subzones (Ramsbottom et al., 1978; Sevastopulo, 2009; Smyth, 1950), including the upper part of the late Serpukhovian. Therefore, the Balrickard Sandstone Formation, on stratigraphical grounds, must represent the lower part of the late Serpukhovian.

In the Ardagh/Kingscourt outlier in north County Meath, $60 \mathrm{~km}$ NW of Dublin (Figure 1), shallow-water platform facies of Brigantian age is represented by the Deer Park Formation. The late Brigantian age was based on the occurrence of the conodonts Lochriea nodosa and L. mononodosa in the upper part of the succession in Barley Hill Quarry, Poulmore Scarp Quarry and in the Almush Stream section (Somerville, 1999; Somerville \& Somerville, 1999). Strogen et al. (1995) distinguished a laterally equivalent facies (the Almush Shale Member of the Loughshinny Formation), which record ammonoids of the $\mathrm{P}_{1 \mathrm{c}}$ to the $\mathrm{P}_{2 c}$ subzones (Jackson, 1965). Thus, the early 
Serpukkhovian can be inferred to represent the upper part of the Deer Park Formation, as well as part of the Almush Shale Member (Figure 2). Foraminifera obtained from the uppermost part of the Deer Park Formation at Poulmore Scarp Quarry (Cózar, Somerville, \& Somerville, 2005a; and new data), include Howchinia subconica, Eolasiodiscus sp. (as Monotaxinoides? sp.), Tubispirodiscus attenuatus, T. cf. cornuspiroides, Planospirodiscus cf. taimyricus from the lower part of the quarry (lower $6 \mathrm{~m}$ ) and Archaediscus at tenuis stage, Cepekia cepeki, Brenckleina sp., Brenckleina rugosa, Eosigmoilina robertsoni, Neoarchaediscus shugorensis, Eostaffellina decurta, E. ex gr. paraprotvae (from $6.8 \mathrm{~m}$ and higher beds), as well as common incertae sedis Algospongia Calcifolium okense throughout the quarry section (Figure 8). Most of the Howchinia species contain umbilical structures, a feature observed from advanced early Serpukhovian times (Cózar et al., 2015). The forms attributed to Eolasiodiscus in Britain were only known previously in the late Serpukhovian (Cózar \& Somerville, 2014; Stephenson et al., 2010), although it has been recorded from the Upper Skateraw Limestone in East Lothian (Scotland), at a level correlated with the Three Yard Limestone in northern England (Alston Block), whereas, Howchinia subconica was recorded from the younger Four Fathom Limestone (Cózar \& Somerville, 2016). Brenckleina, Eosigmoilina and Archaediscus at tenuis stage was also recorded from the Four Fathom Limestone, although recent discoveries have identified the presence of $A$. at tenuis stage in the Three Yard Limestone (Cózar \& Somerville, in press). On the other hand, the Eostaffellina species have been recorded from the Three Yard Limestone. In the Alston Block, the acme of Calcifolium okense is located between the Three Yard Limestone Member and the Great Limestone Member (Cózar \& Somerville, 2004, 2016), although its first occurrence is from the Five Yard Limestone (Cózar \& Somerville, 2004). All those members were considered as equivalent to the Steshevian, although the upper part of the Poulmore Scarp Quarry yielding Eosigmoilina and Brenckleina is correlated with the Four Fathom Limestone, and the lower part of the quarry should be correlated with the Three Yard Limestone Member, and thus, it might be the lower part of the Steshevian (Figures 2, 4). This interval is also represented by the basinal Almush Shale Member, laterally equivalent to the platform Deer Park Limestone Formation. Younger strata are represented by the Ardagh Shale Formation, ranging from the $E_{1 a}$ to $E_{1 c}$ subzones (Jackson, 1965). Although there is a continuous 
succession between the Deer Park and Ardagh Shale fomations, a small hiatus between both formations had been previously suggested (Somerville, Strogen, Jones, \& Somerville, 1996b; Strogen et al., 1995), although it is now considered of lesser importance (Figure 2). The Carrickleck Shale Formation which succeeds the Ardagh Shale Formation ranges in age from the $\mathrm{E}_{2 a}$ to $\mathrm{H}_{2 c}$ (Somerville \& Waters, 2011c). Thus, the upper part of the early Serpukhovian up to the lower part of the late Serpukhovian corresponds with the Ardagh Shale Fomation, and the upper part of the late Serpukhovian is included within the lower part of the Carrickleck Shale Formation.

\subsection{Northwest Carboniferous Basin and Slieve Carna Outlier}

In the Slieve Carna outlier (County Mayo), a shaley succession is recorded. It comprises the Tooromin Shale and Craggagh Shale formations (Long, McConnell, \& Philcox, 2004). According to ammonoids listed by Ramsbottom et al. (1978), the Tooromin Shale includes the $P_{2}$ zone, and the Craggah Shale contains the $E_{1 a}$ to $E_{1 c}$ subzones, and thus, most of the early Serpukhovian seems to be present and only the lower part of the late Serpukhovian (Figure 2). The lack of any limestones in the succession does not allow the confirmation of these biostratigraphic ages using foraminifers and conodonts. No other putative Serpukhovian rocks are known in Western Ireland (see Pracht \& Somerville, 2015; Somerville \& Waters, 2011b).

In the Northwest Carboniferous Basin (counties Sligo, Leitrim, and western Fermanagh) there is a relatively uniform succession (Leitrim Group), and the BrigantianArnsbergian interval is well exposed around the Cuilcagh Mountains, close to Lough Allen (Legg, Johnston, Mitchell, Smith, 1998; Somerville \& Waters, 2011a; Figure 1). The lower part of the Leitrim Group (upper Viséan) is composed of the Meenymore, Glenade Sandstone, Bellavally and Carraun Shale formations (Brandon \& Hodson, 1984; Legg et al., 1998), ranging from the $B_{2 a}$ to $P_{2 c}$ ammonoid subzones (Brandon, 1977; Brandon \& Hodson, 1984) (Figure 2). Aldridge et al. (1968) recorded Lochriea nodosa and L. mononodosa from the middle part of the Carraun Shale Formation, and 
Barham et al. (2015) recorded L. nodosa, L. mononodosa, together with L. cruciformis, L. ziegleri and L. senckenbergica from similar levels, in the Ardvarney Limestone Member and Sranagross Dolomite Member (Carraun Shale Formation). Sevastopulo and Wyse Jackson (2009) considered the Meenymore and Glenade Sandstone formations as Asbian in age, and the Bellavally and Carraun Shale formations as Brigantian. However, Kelly (1989) recorded L. nodosa from the basal Meenymore Formation. Somerville and Waters (2011a) considered the Meenymore and Bellavally formations as early Brigantian in age, with the boundary between the early Brigantian and late Brigantian located in the middle part of the Carraun Shale Formation. On the other hand, as Cózar et al. $(2006,2019)$ mentioned, the Tullyskeherny Member, at the base of the Bellavally Formation, contains Neoarchaediscus postrugosus form 2, $N$. gregorii and Planospirodiscus aff. taimyricus (Figure 9a-h), which allow us to establish that the base of the Serpukhovian is located at or below the base of the Bellavally Formation (Figure 4). The assemblage is similar to that recorded in upper positions of the unit 3 in the Clogrenan Formation, and similarly, it is correlated with levels equivalent to the Scar Limestone of northern England. A similar assemblage is recorded near the top of the Bellavally Formation, Sheena Shale Member, where more evolved Planospirodiscus first occur (Figure 9i-I). At the base of the succeeding Carraun Shale Formation, within the Derreens Limestone Member, Neoarchaediscus with some whorls at tenuis stage, Tubispirodiscus and Archaediscus at tenuis stage are recorded. (Figure 9i-u). These taxa can be compared to other outcrops in Ireland and Britain, suggesting a probable Steshevian foraminiferal assemblage for the Carraun Shale Formation, in particular, the lower part of this substage, equivalent to the Three Yard Limestone (Figures 2, 4). This substage extends up to the Dergvone Shale Formation (upper part of the Leitrim Group), which includes the first occurrence of Cravenoceras leion (Brandon \& Hodson, 1984). The overlying Briscloonagh Sandstone Formation does not contain any palaeontological records, and it is assumed to represent the rest of the Pendleian, because the succeeding Gowlaun Shale Formation contains faunal markers of the Arnsbergian $E_{2 a}$ subzone (MacDermot, Long, \& Harney, 1996). Above, the Lackagh Sandstone Formation has no faunal records (Legg et al., 1998), and the veneering Bencroy Shale Formation, which only crops out in Co. Leitrim, contains 
ammonoids of the $E_{2 b 1}$ subzone (Brandon \& Hodson, 1984; Ramsbottom et al., 1978) (Figure 2).

\subsection{Northern Ireland}

In Northern Ireland, apart from the Cuilcagh Mountains area which contains the Leitrim Group (see section 3.5), there are other regions where Serpukhovian rocks are present. In the south, in County Armagh, close to the Kingscourt outlier (Figure 1), in the Armagh Platform succession, the youngest Viséan strata comprise the Carganamuck Limestone Formation (Figure 2), ranging in age from early to late Brigantian (Mitchell \& Somerville, 2011). However, Cózar et al. (2005a) established that most of the $>35-\mathrm{m}$-thick unit is late Brigantian, with only the lower 7 metres of the formation assigned to the early Brigantian. The late Brigantian age was based on the FAD of Janischewskina typica and Endothyranopsis sphaerica, and thus, this interval can be correlated with the Five Yard Limestone in the early Serpukhovian (Figure 2). A remarkable first occurrence is that of Calcifolium okense (rare) and Neoarchaediscus shugorensis. These taxa in the upper part of the formation suggest a level equivalent to the basal level of the Steshevian, equivalent to the Three Yard Limestone in northern England (Figure 4) (similar to the upper beds of the Deer Park Formation in the Kingscourt outlier, $40 \mathrm{~km}$ to the south). Unfortunately, younger Mississippian strata are not preserved, as the top of the succession is eroded beneath Triassic rocks.

In the centre of Northern Ireland, in Cookstown, County Tyrone (Figure 1), the upper part of the Rockdale Limestone Formation contains the base of the late Brigantian (Mitchell \& Somerville, 2011), and Brigantian-aged rocks are also present in the succeeding Rossmore Mudstone Formation (Figure 2), with ammonoids of the $\mathrm{P}_{2 \mathrm{a}}$ subzone in its lower part (Robbie, 1955). The upper part of the Rockdale Limestone Formation was studied in Cookstown Quarry and in the Ballytrea Borehole (Cózar et al., 2005a; Somerville, 1999; Somerville \& Somerville, 1999). Although the borehole 
contains very poor foraminiferal assemblages, the upper part of the quarry yields Janischewskina typica and Biseriella parva, as well as the conodonts Lochriea nodosa and $L$. mononodosa, which can be correlated with the early Serpukhovian. Older levels in the quarry also include Neoarchaediscus gregorii, Neoarchaediscus postrugosus form 1 and Climacammina, which can be correlated with the Single Post/Cockleshell limestone interval at the base of the Serpukhovian (Figure 4). A single occurrence of Calcifolium okense might suggest equivalence to the Five Yard Limestone Member (Cózar \& Somerville, 2004), although its acme occurs from the Three Yard limestone upward (see above). Similarities with the top of the Carganamuck Limestone Formation, including also the first occurrence of Biseriella parva, suggest that the top part of the Rockdale Limestone is most probably equivalent also to the Three Yard Limestone Member (Figure 4). There is no biostratigraphic dating of the upper part of the Rossmore Mudstone Formation, but the succeeding Millstone Grit Group contains NC-TK miospore zones, equivalent to the $E_{1 b}$ to $E_{2 b}$ (Ramsbottom et al., 1978). Thus, the Rossmore Mudstone Formation is also considered to be of early Serpukhovian age, whereas the Millstone Grit Group extends from the upper part of the early Serpukhovian to most of the late Serpukhovian (Figure 2).

The Fintona Block in Kesh-Omagh is the only succession in Ireland which is exclusively composed of continental alluvial sediments (Mitchell \& Owens, 1990). The NM and VF Miospore biozones were recorded from the Topped Mountain Sandstone, whereas most of the early Brigantian Ballyreagh Conglomerate Formation is not dated, and the NC biozone was recognized in the succeeding Ballinamallard Mudstone Formation, which extends upwards to the Pendleian (Mitchell \& Somerville, 2011). This suggests that the base of the Serpukhovian lies within the Ballyreagh Conglomerate Formation, and the Ballynamallard Mudstone Formation represents the rest of the early Serpukhovian (Figure 2). The biostratigraphy in this region cannot be more precise, because of the generalized absence of fauna. In parallel, the Greenan Sandstone Formation was also dated as VF biozone, but from the lower part of the formation, and thus, its upper range is unknown, possibly ranging into the Serpukhovian. Michell and Owens (1990), and Sevastopulo (2009) considered that the upper part of the formation extended through the Pendleian. 
On the north coast, in County Antrim (Figure 1), the Ballycastle Group is rather poorly studied, but contains the early Brigantian VF biozone in the lower levels, and ammonoids of the $\mathrm{P}_{2 \mathrm{~b}}$ biozone from the upper part (Mitchell, 2004; Mitchell \& Somerville, 2011), which allow to infer the occurrence of the Serpukhovian in this group. Foraminiferal assemblages in the upper part of the group, from the Main Limestone Member (Mitchell, 2004), contain numerous Asteroarchaediscus, Neoarchaediscus, Archaediscus, Planospirodiscus and Tubispirodiscus. This assemblage typically occurring in the early Serpukhovian levels equivalent to the Tarusian, but samples near the top of the member also contain Planospirodiscus taimyricus, $P$. minimus, Neoarchaediscus gregorii, as well as Eostaffellina aff. decurta (Figure 10). This latter taxon suggests that the group reaches the lower part of the Steshevian, and the foraminiferal assemblage is typical of the Three Yard Limestone in northern England. This succession was interpreted by Sevastopulo (2009) as the Ballyvoy Sandstone Formation of Mitchell (2004), and of late Brigantian and Pendleian age. Sevastopulo (2009) based the lithological correlation on the so-called Main Coal with horizons also located nearly at the base of the Millstone Grit Group (Wilson \& Robbie, 1966).

\section{SUMMARY AND IMPLICATIONS}

One of the main implications arising from this study, is that Serpukhovian rocks in Ireland are 'not almost exclusively terrigenous, with rare limestones', as claimed by previous authors (e.g., Sevastopulo, 2009, p. 269), but that they include the upper part of the thick platform limestones successions throughout much of Ireland, previously referred to as upper Viséan in age. It is agreed, though, that the change from carbonate to siliciclastic sedimentation was not synchronous, and not always coincident with the base of the Pendleian. It is evident from the foraminiferal data, that rocks of Serpukhovian age are present in County Carlow (Clogrenan Formation), County Clare (Slievenaglasha and Magowna formations), County Meath (Deer Park Formation), County Armagh (Carganamuck Limestone Formation) and County Tyrone (Rockdale Limestone Formation), in areas where there occurred continuous shallow- 
water platform limestone sedimentation. In these thick limestone units (typically 50$100 \mathrm{~m}$ thick), Tarusian (and in some cases Steshevian) foraminiferal assemblages are recorded (Figure 4).

The assemblage in the lower part of the Clogrenan Formation (County Carlow) is characterised by the presence of primitive Planospirodiscus and Neoarchaediscus gregorii, followed immediately by Neoarchaediscus postrugosus form 1, which are considered representative of the Single Post Limestone and Cockleshell Limestone in the Alston Block in northern England (assemblage 6), equivalent to the latest Venevian age (Figure 4). The higher beds in the Clogrenan Formation, and in the Ballyelly Member of the Slievenaglasha Formation in the Burren, record Neoarchaediscus gregorii, Neoarchaediscus postrugosus form 2, Planospirodiscus taimyricus, "Millerella tortula" Janischewskina typica and Endothyranopsis sphaerica. These foraminiferal assemblages can be correlated with similar assemblages in the Scar-Five Yard limestones (Alston Block) in northern England (Cózar \& Somerville, 2004, 2014, 2016, in press; Figures 2, 4) and possibly representing a late Tarusian age. Other successions in south central Ireland, such as the Liscarroll Limestone Formation and Dromkeen Limestone Formation, do not have any representatives of Serpukhovian foraminiferal assemblages, with the youngest taxa present being of late Viséan age.

In Northern Ireland within the Carganamuck Limestone Formation (County Armagh), although this succession has been eroded beneath the unconformity with the overlying Triassic strata, early Serpukhovian foraminiferal assemblages with Janischewskina typica and Endothyranopsis sphaerica are recorded from the lower beds. Furthermore, the rare presence of Calcifolium okense and Neoarchaediscus shugorensis establish that the highest beds are equivalent to the Three Yard Limestone in the Alston Block (Figure 4). The youngest beds of the Rockdale Limestone Formation (County Tyrone) contain Janischewskina typica and Biseriella parva, as well as rare Calcifolium okense, suggesting equivalence to the Five Yard Limestone Member, and the top of the formation equivalent to the Three Yard Limestone (Figure 4).

The youngest beds of the Deer Park Formation (County Meath) record Archaediscus at tenuis stage, Eolasiodiscus, Brenckleina, Eosigmoilina, Cepekia cepeki, Eostaffellina, 
Neoarchaediscus shugorensis and abundant Calcifolium okense. This foraminiferal assemblage can be correlated with similar assemblages in the Three Yard Limestone (Alston Block) in northern England (Cózar \& Somerville, 2004, 2014, 2016, in press; Figures 2, 4) of the upper part of the early Serpukhovian.

In County Clare the youngest beds of the Slievenaglasha Formation (Lissylisheen Member) have recorded late Steshevian foraminiferal assemblages, with the presence of Archaediscus at tenuis stage, Cepekia cepeki, Eolasiodiscus, Eosigmoilina, Neoarchaediscus shugorensis and Tubispirodiscus simplissimus. These beds can be correlated with the Four Fathom Limestone in northern England (Cózar \& Somerville, 2004, 2014, 2016, in press; Figures 2, 4). In the thin overlying Magowna Formation, a similar assemblage is recorded, together with Brownediscus?, Brenckleina and Eosigmoilina, of late early Serpukhovian age, and correlated with the assemblage 10 in northern England (Great Limestone and Little limestones).

The most important foraminifers recorded from the Main Limestone in Ballycastle (County Antrim) are Planospirodiscus taimyricus, Neoarchaediscus gregorii and Eostaffellina aff. decurta which are of likely late early Serpukhovian age.

The shallow-water platform limestones of late Viséan-Serpukhovian age in Ireland have prolific foraminiferal faunas and record import evolutionary changes, especially within the archaediscid group. In several sections, notably the Clogrenan Formation, a succession of distinct evolutionary events can be recognised, with the FAD of Neoarchaediscus gregorii, followed by Neoarchaediscus postrugosus form 1, and Neoarchaediscus postrugosus form 2. In Russia N. postrugosus is currently used as the marker taxon to define the base of the Serpukhovian (Gibshman, 2003; Kulagina et al., 2011, Nikolaeva et al., in press). What is particularly unique about most of the upper Viséan-Serpukhovian successions in Ireland (except Cuilcagh Mountains and Ballycastle), is that they are represented by thick continuous limestone units, unlike most other coeval successions in northern Europe which are cyclothemic, with thin limestone beds alternating with thick clastic units, e.g. Moscow Basin, Urals, Ukraine, Poland, northern England and Scotland. Thus, in Ireland, evolutionary lineages can be 
recorded, whereas in most other successions, only discrete foraminiferal events are preserved in the cyclothemic limestones.

Another major implication of the above faunal data concerns the palaeogeography. The recognition of Tarusian and in some cases Steshevian foraminiferal assemblages in the limestones, implies that many of the shallow-water platform areas in Ireland during the upper Viséan (Brigantian substage) persisted into the Early Serpukhovian.

\section{CONCLUSIONS}

One of the main conclusions arising from this study on Mississippian rocks in Ireland, is that limestone formations which were previously excluded from the Serpukhovian are now recognised, in part, on faunal grounds, as belonging to the lower two substages of the Serpukhovian. A reassessment of previous foraminiferal determinations, together with new foraminiferal data, has confirmed that rock equivalent to the Tarusian and Steshevian substages are present in several sections. In the Slievenaglasha Formation and Magowna Formation (County Clare) and Deer Park Formation (County Meath), Tarusian and Steshevian foraminiferal assemblages are recorded. In the Clogrenan Formation (County Carlow), Carganamuck Limestone Formation (County Armagh) and Rockdale Limestone Formation (County Tyrone), Tarusian foraminiferal assemblages are recorded in the upper beds of thick limestone successions. Key foraminiferal and algal taxa characterise each assemblage, which have been correlated with equivalent Serpukhovian strata in the north of England and Scotland. A three-stage evolution is recognised in archaediscid foraminifers: from Neoarchaediscus gregorii, followed by Neoarchaediscus postrugosus form 1, and Neoarchaediscus postrugosus form 2, with Neoarchaediscus postrugosus form 1, used to define the base of the Serpukhovian. The recognition of Tarusian and Steshevian foraminiferal assemblages, implies that areas of shallow-water platform carbonate sedimentation in Ireland during the upper Viséan (Brigantian) persisted into the Early Serpukhovian. 


\section{ACKNOWLEDGEMENTS}

We would like to thank D. Vachard and Q. Y. Sheng for their constructive comments. This research was funded by the Spanish Ministry of Ciencia, Investigación y Universidades (project CGL2016-78738BTE).

\section{STATEMENT OF CONFLICT OF INTEREST}

The authors of the paper declare that there are no potential sources of conflict of interest.

ORCID

Pedro Cózar https://orcid.org/0000-0002-4669-8702

Ian Somerville https://orcid.org/0000-0001-8379-9097

\section{REFERENCES}

Aizenverg, D. E., Brazhnikova, N. E., Vassilyuk, N. P., Reitlinger, E. V., Fomina, E. V., \& Einor, O. L. (1979). The Serpukhovian stage of the Lower Carboniferous of the USSR. In R. H. Wagner, A. C. Higgins \& S. V. Meyen, (Eds.). The Carboniferous of the USSR (pp. 43-59). Leeds: Yorkshire Geological Society, Occasional Publication 4.

Aldridge, R. J., Austin, R. L., \& Husri, S. (1968). Viséan conodonts from north Wales and Ireland. Nature, 219, 255-258.

Archer, J. B., Sleeman, A. G., \& Smith, D. C. (1996). Geology of Tipperary. A geological description of Tipperary and adjoining parts of Laois, Kilkenny, Offaly, Clare and Limerick, to accompany the Bedrock Geology 1:100,000 Scale Map Series, Sheet 
18, Tipperary, with contributions by K. Claringbold, G. Stanley (Mineral Resources) and G. Wright (Groundwater Resources). Dublin: Geological Survey of Ireland.

Austin, R. L. (1973). Modification of the British Avonian conodont zonation and a reappraisal of European Dinantian conodont zonation and correlation. Annales de la Société géologique de Belgique, 96, 523-532.

Austin, R. L., \& Husri, S. (1974). Dinantian conodont faunas of County Clare, County Limerick and County Leitrim. In J. Bouckaert, \& M. Streel (Eds.), International Symposium on Belgian Micropaleontological Limits, from Emsian to Viséan, Namur, 1974. Geological Survey of Belgium, 3, 18-69.

Austin, R. L., Conil, R., \& Husri, S. (1970). Correlation and age of the Dinantian rocks north and south of the Shannon, Ireland. Congrès et Colloques Université Liège, 55, 179-192.

Austin, R. L., Conil, R., Groessens, E., \& Pirlet, H. (1974). Étude biostratigraphique de l'encrinite de Tramaka. Bulletin de la Société belge de Géologie Paléontologie Hydrologie, 83, 113-129.

Barham, M., Murray, J., Sevastopulo, G. D., \& Williams, D. M. (2015). Conodonts of the genus Lochriea in Ireland and the recognition of the Viséan-Serpukhovian (Carboniferous) boundary. Lethaia, 48, 151-171.

Bowden, A. (2001). The Asbian to Arnsbergian conodonts and sequence stratigraphy of the Northumberland Trough. Durham: Ph.D. Durham University.

Braithwaite, K. (1993). Stratigraphy of a Mid-Carboniferous section at Inishcorker, Ireland. Annales de la Société Géologique de Belgique, 116, 209-19.

Braithwaite, K. (1995). Stratigraphy of the mid-Carboniferous boundary. Leeds: Ph.D. University of Leeds.

Brand, P. J. (2011). The Serpukhovian and Bashkirian (Carboniferous, Namurian and basal Westphalian) faunas of northern England. Proceedings of the Yorkshire Geological Society, 58, 143-165. 
Brandon, A. (1972). The upper Viséan and Namurian shales of the Doagh outlier, County Fermanagh, Northern Ireland. Irish Naturalists' Journal, 17, 159-170.

Brandon, A. (1977). The Meenymore Formation - an evaporitic intertidal formation in the Upper Viséan (B2) of northwest Ireland. Belfast: Institute of Geological Sciences Report No. 77/23.

Brandon, A., \& Hodson, F. (1984). The Stratigraphy and Palaeontology of the Late Viséan and Early Namurian rocks of North-east Connaught. Geological Survey of Ireland Special Paper, No. 6, 1-54.

Brenckle, P. L., \& Grelecki, C. J. (1993). type Archaediscacean Foraminifers (Carboniferous) from the Former Soviet Union and Great Britain with a Description of Computer Modeling of Archaediscacean Coiling. Cushman Foundation for Foraminiferal Research, Special Publication, 30, 1-59.

Brenckle, P. L., Ramsbottom, W. H., \& Marchant, T. R. (1987). Taxonomy and classification of Carboniferous archaediscacean foraminifers. Courier Forschungsinstitut Senckenberg, 98, 11-24.

Clarke, M. J. (1966). Orionastraea in Ireland. Irish Naturalists' Journal, 15, 177-178.

Clayton, G., Sevastopulo, G. D., \& Sleeman, A. G. (1986). Carboniferous (Dinantian and Silesian) and Permo-Triassic rocks in south County Wexford. Geological Journal, $21,355-374$.

Conil, R., Longerstaey, P. J., \& Ramsbottom, W. H. C. (1980). Matériaux pour l'étude micropaléontologique du Dinantien de Grande-Bretagne. Mémoires de l'Institut de Géologie de l'Université de Louvain, 30, 1-187.

Cózar, P., \& Somerville, I. D. (2004). New algal and foraminiferal evidence for the recognition of the Asbian/Brigantian boundary in northern England. Proceedings of the Yorkshire Geological Society, 55, 43-65.

Cózar, P., \& Somerville, I. D. (2005). Stratigraphy of Upper Viséan rocks in the Carlow area, southeast Ireland. Geological Journal, 40, 35-64. 
Cózar, P., \& Somerville, I. D. (2013). The Carboniferous Archerbeck Borehole, near Canonbie (Dumfriesshire, southern Scotland): biostratigraphic revision of the late Asbian to early Pendleian succession using foraminiferans and regional correlations. Earth and Environmental Science Transactions of Royal Society of Edinburgh, 103, 105-122.

Cózar, P., \& Somerville, I. D. (2014). Latest Viséan-early Namurian (Carboniferous) foraminifers from Britain: implications for biostratigraphic and glacioeustatic correlations. Newsletters on Stratigraphy, 47, 355-367.

Cózar, P., \& Somerville, I. D. (2016). Problems correlating the late BrigantianArnsbergian Western European substages within northern England. Geological Journal, 51, 817-840.

Cózar, P., \& Somerville, I. D. (in press). Foraminiferal biostratigraphy of upper ViséanArnsbergian limestones from eastern Scotland and Northumberland (northeast England). Earth and Environmental Science Transactions of Royal Society of Edinburgh.

Cózar, P., Somerville, H. E. A., \& Somerville, I. D. (2005a). Foraminifera, calcareous algae and rugose corals in Brigantian (late Viséan) limestones in NE Ireland. Proceedings of the Yorkshire Geological Society, 55, 287-300.

Cózar, P., Somerville, I. D., Aretz, M., \& Herbig, H.-G. (2005b). Biostratigraphical dating of Upper Viséan limestones (NW Ireland) using foraminifera, calcareous algae and rugose corals. Irish Journal of Earth Sciences, 23, 1-21.

Cózar, P., Somerville, I. D., Mitchell, W.I., \& Medina-Varea, P. (2006). Correlation of Mississippian (Upper Viséan) foraminiferan, conodont, miospore and ammonoid zonal schemes, and correlation with the Asbian- Brigantian boundary in northwest Ireland. Geological Journal, 41, 221-241.

Cózar, P., Somerville, I. D., \& Burgess, I. (2008). New foraminifers in the Visean/Serpukhovian boundary interval of the Lower Limestone Formation, Midland Valley, Scotland. Journal of Paleontology, 82, 906-923. 
Cózar, P., Somerville, I. D., \& Burgess, I. C. (2010). Foraminiferal, calcareous algal and problematica assemblages from the Mississippian Lower Limestone Formation in the Midland Valley, Scotland. Earth and Environmental Science Transactions of Royal Society of Edinburgh, 100, 207-309.

Cózar, P., Sanz-López, J., \& Blanco-Ferrera, S. (2015). Lasiodiscid foraminifers during the late Viséan to Serpukhovian in Vegas de Sotres section (Cantabrian Mountains, NW Spain): Potential biostratigraphic markers for the Viséan-Serpukhovian boundary. Geobios, 48, 213-238.

Cózar, P., Somerville, I. D., Sanz-López, J., \& Blanco-Ferrera, S. (2016). Foraminiferal biostratigraphy across the Visean/Serpukhovian boundary in the Vegas de Sotres section (Cantabrian Mountains, Spain). Journal of Foraminiferal Research, 46, 171192.

Cózar, P., Vachard, D., Aretz, M., \& Somerville, I. D. (2019). Foraminifers of the ViséanSerpukhovian boundary interval in Western Palaeotethys: a review. Lethaia, 52, 260-284.

Davies, R. B., Austin, R. L., \& Moore, D. (1993). Environmental controls of Brigantian conodont-distribution: Evidence from the Gayle Limestone of the Yoredale Group in Northern England. Annales de la Société géologique de Belgique, 116, 221-241.

Davydov, V. I., Crowley, J. L., Schmitz, M.D., \& Poletaev, V. I. (2010). High precision U$\mathrm{Pb}$ zircon age calibration of the global Carboniferous time scale and Milankovitch band cyclicity in the Donets Basin, eastern Ukraine. Geochemistry, Geophysics, Geosystems, 11, Q0AA04, doi: 10.1029/2009GC002736.

Davydov, V. I., Korn, D., Schmitz, M. D., Gradstein, F. M., \& Hammer, O. (2012). Chapter 23-The Carboniferous Period. In F. M. Gradstein, J.G. Ogg, M.D. Schmitz \& G.M. Ogg (Eds.), The Geologic Time Scale 2012 (pp. 603-651). Amsterdam: Elsevier. 
Dunham, K. C. (1990). Geology of the Northern Pennine Orefield, Volume 1 Tyne to Stainmore. Economic Memoir of the British Geological Survey, Sheets 40, 41 and 45. London: HMSO.

Dunham, K. C., \& Stubblefield, C. J. (1945). The stratigraphy, structure and mineralization of the Greenhow mining area, Yorkshire. Quarterly Journal of the Geological Society of London, 100, 209-268.

Einor, O. L. (1996). The former USSR. In R.H. Wagner, C F. Winkler Prins \& L. F. Granados (Eds.), The Carboniferous of the World III, The former USSR, Mongolia, Middle Eastern Platform, Afghanistan and Iran (pp. 13-404). Madrid: IUGS Publication No. 33. Instituto Geológico y Minero de España/ Nationaal Natuurhistorisch Museum.

Fallon, P., \& Murray, J. (2015). Conodont biostratigraphy of the mid-Carboniferous boundary in Western Ireland. Geological Magazine, 152, 1025-1042.

Gallagher, S. J. (1992). Lithostratigraphy, biostratigraphy and palaeoecology of Upper Dinantian platform carbonates in parts of southern and western Ireland. Dublin: Unpublished PhD thesis, University College Dublin (National University of Ireland).

Gallagher, S. J. (1996). The stratigraphy, and cyclicity of late Dinantian platform carbonates in parts of southern and western Ireland. In P. Strogen, I. D. Somerville \& G. LL. Jones (Eds.), Recent Advances in Lower Carboniferous Geology (pp. 239251). Oxford: Geological Society, London, Special Publications, 107.

Gallagher, S. J., MacDermot, C. V., Somerville, I. D., Pracht, M., \& Sleeman, A. G. (2006). Biostratigraphy, microfacies and depositional environments of Upper Viséan limestones from the Burren region, County Clare, Ireland. Geological Journal, 41, 61-91.

Gallagher, S. J., \& Somerville, I. D. (1997). Late Dinantian (Lower Carboniferous) platform carbonate stratigraphy of the Buttevant area North Co. Cork, Ireland. Geological Journal, 32, 312-335. 
Ganelina, R. A. (1956). Foraminifera of the Viséan deposits of the northwest region of the lower Moscow basin. Mikrofauna SSSR, Trudy Vsesoyuznogo NauchnoIssledovatel'skogo Geologorazvedochnogo Instituta VNIGRI, 98, 61-159 (in Russian).

George, T. N., \& Wagner, R. H. (1972). I.U.G.S. Subcommission on Carboniferous Stratigraphy. Proceedings of the General Assembly at Krefeld, August, 21-22. In Compte Rendu VII Congrès International de Stratigraphie et de Géologie du Carbonifère, volume I (pp. 139-147). Krefeld 1971.

George, T. N., Johnson, G. A. L., Mitchell, M., Prentice, J. E., Ramsbottom, W. H. C., Sevastopulo, G. D., \& Wilson, R. B. (1976). A Correlation of Dinantian rocks in the British Isles. London: Geological Society Special Report, 7.

Gibshman, N. B. (2003). Foraminifers from the Serpukhovian Stage Stratotype, the Zabor'e Quarry (Moscow Region). Stratigraphy and Geological Correlation, 11, 3963 (in Russian).

Gibshman, N. B. (2019). Morphological evolution and detailed biostratigraphy of Eostaffellina Reitlinger, 1963 (Foraminifera) in the Serpukhovian stage of the Moscow Basin. In Bogdanova, T. N., Brugrova, E.M., Vuks, V. Ya., et al. (Eds.), Morphologic evolution and stratigraphical problems; Season LXV Palaeontologica Society, St Petersburg 2019 (pp. 39-41). VSEGEI, St Petersburg (in Russian).

Graham, J. R. (1975). Analysis of an Upper Palaeozoic transgressive sequence in southeast County Cork, Eire. Sedimentary Geology, 13, 267-29.

Hallett, D. (1971). Foraminifera and algae from the Yoredale 'Series' (Viséan-Namurian) of northern England. In Compte Rendu 6e Congrès International Stratigraphie et Géologie Carbonifère, volume III (pp. 873-901), Sheffield, 1967.

Higgs, K. (1986). The stratigraphy of the Namurian rocks of the Leinster Coalfield. Geological Survey of Ireland Bulletin, 3, 257-277. 
Holliday, D., Burgess, I. C., \& Frost, D. V. (1975). A recorrelation of the Yoredale Limestones (Upper Viséan) of the Alston Block with those of the Northumberland Trough. Proceedings of the Yorkshire Geological Society, 40, 319-334.

Herbig, H.-G. (2017). Taxonomic and stratigraphic problems concerning the conodonts Lochriea senckenbergica Nemirovskaya, Perret \& Meischner, 1994 and Lochriea ziegleri Nemirovskaya, Perret \& Meischner, 1994 - Consequences for defining the Viséan-Serpukhovian boundary. Newsletter on Carboniferous Stratigraphy, 33, 2835.

Hodson, F., \& Lewarne, G. (1961). A mid-Carboniferous Namurian basin in parts of the counties of Limerick and Clare, Ireland. Quarterly Journal of Geological Society, London, 117, 307-333.

Hodson, F., \& Moore, E. W. J. (1959). Goniatites striatus and related forms from the Viséan of Ireland. Palaeontology, 1, 384-396.

Jackson, J. S. (1965). The Upper Carboniferous (Namurian and Westphalian) of Kingscourt, Ireland. Scientific Proceedings of the Royal Dublin Society, 2, 131-152.

Johnson, G. A. L., Somerville, I. D., Tucker, M. E., \& Cózar, P. (2011). Carboniferous stratigraphy and context of the Seal Sands No. 1 Borehole, Teesmouth, NE England: the deepest onshore borehole in Great Britain. Proceedings of the Yorkshire Geological Society, 58, 173-196.

Jones, G. LL., \& Somerville, I. D. (1996). Irish Dinantian biostratigraphy: practical application. In: P. Strogen, I. D. Somerville \& G. LL. Jones (Eds.), Recent Advances in Lower Carboniferous Geology (pp. 253-262). Oxford: Geological Society, London, Special Publications, 107.

Karbub, A. M. (1993). Foraminiferal biostratigraphy and microfacies of the Lower Carboniferous rocks, Central Scotland. Edinburgh: M. Ph. Thesis University of Edinburgh. 
Kelk, B. (1960). Studies in the Carboniferous stratigraphy of Western Eire. Reading: Ph. D. thesis, University of Reading.

Kelly, J. G. (1989). The Late Chadian - Brigantian Geology of the Carrick-on-Shannon and Lough Allen Synclines, North West Ireland. Dublin: Unpublished PhD thesis, University College Dublin (National University of Ireland).

Khimenkhov, V. G. (1934). General geological map of the European part of the URSS. Sheet 43. Kalinin-Mozhaysk-Dukhovshchina-Toropets. Moscow: Trudy Moskovskogo Geologo-Hidro-Geodezichskogo Tresta (in Russian).

Korn, D. (1990). On the Upper Viséan goniatite succession in North Leitrim. Irish Journal of Earth Sciences, 10, 109-114.

Korn, D., \& Titus, A. L. (2011). Goniatites zone (middle Mississippian) ammonoids of the Antler foreland basin (Nevada, Utah). Bulletin of Geosciences, 86, 107-196.

Kulagina, E. I. (2017). Foraminifers of the genus Neoarchaediscus Miklukho-Maclay, 1956: species compositions and its significance for Carboniferous stratigraphy. Geologicheskiy Sbornik, 13, 16-24 (in Russian).

Kulagina, E.I., Stepanova, T.I., Kucheva, N.A., \& Nikolaeva, S.V. (2011). The ViséanSerpukhovian boundary on the eastern slope of the South Urals. Newsletters on Carboniferous Stratigraphy, 29, 50-56.

Lane, H. R., \& Brenckle, P. L. (2005). Type Mississippian subdivisions and biostratigraphic succession. In Ph. H. Heckel (Ed.), Stratigraphy and biostratigraphy of the Mississippian Subsystem (Carboniferous System) in its Type Region, the Mississippi River Valley of Illinois, Missouri, and lowa (pp. 76-105). Champaign: IUGS Subcommission on Carboniferous Stratigraphy Guidebook 34.

Legg, I. C., Johnston, T. P., Mitchell, W. I., \& Smith, R. A. (1998). Geology of the Country around Derrygonnelly and Marble Arch. Belfast: Memoir of the Geological Survey of Northern Ireland, Sheets $44,56 \& 43$ (Northern Ireland). 
Long, C. B., McConnell, B. J., \& Philcox, M. E. (2004). Geology of South Mayo. A geological description to accompany the bedrock geology 1:100,000 scale map series, Sheet 11, South Mayo with contributions by W. Cox and U. Leader. Dublin: Geological Survey of Ireland.

MacDermot, C. V., Long, C. B., \& Harney, S. J. (1996). Geology of Sligo - Leitrim. A geological description of Sligo, Leitrim and adjoining parts of Cavan, Fermanagh, Mayo and Roscommon, to accompany bedrock geology 1:100 000 scale map series, Sheet 7, Sligo - Leitrim with contributions by K. Claringbold, G. Stanley, D. Daly and R. Meehan. Dublin: Geological Survey of Ireland.

McLean, D., Owens, B., Bodman, D. J., \& McLean, F. D. (2018). Miospores from the Brigantian stratotype section at Janny Wood, Cumbria. Proceedings of the Yorkshire Geological Society, 62, 89-100.

Metcalfe, I. (1981). Conodont zonation and correlation of the Dinantian and early Namurian strata of the Craven lowlands of Northern England. Report of the Institute of Geological Sciences, 80/10, 1-70.

Mitchell, M. (1989). Biostratigraphy of Viséan (Dinantian) rugose coral faunas from Britain. Proceedings of the Yorkshire Geological Society, 47, 233-247.

Mitchell, W. I. (2004). Carboniferous. In: W. I. Mitchell (Ed.), The Geology of Northern Ireland-Our Natural Foundation (pp. 79-116). Belfast: Geological Survey of Northern Ireland.

Mitchell, W. I., \& Owens, B. (1990). The geology of the western part of the Fintona Block, Northern Ireland: evolution of Carboniferous basins. Geological Magazine, $127,407-426$.

Mitchell, W. I., \& Somerville, I. D. (2011). Northern Ireland. In C. N., Waters, I. D., Somerville, N. S. Jones et al. (Eds.), A revised correlation of Carboniferous rocks in the British Isles (pp. 119-127). Dorchester: The Geological Society, London, Special Report 26. 
Moore, E. W. J. (1958). Dimorphoceratidae from the Upper Viséan shales of County Leitrim, Eire. Proceedings of the Yorkshire Geological Society, 31, 219-226.

Nagy, Z. R., Somerville, I. D., Gregg, J. M, Becker, S. P, Shelton, K. L., \& Sleeman, A. G. (2005). Sedimentology and Stratigraphy of Upper Tournaisian -Viséan (Mississippian, Lower Carboniferous) carbonate rocks in south County Wexford, Ireland: an example of sedimentation in an actively tilting half-graben. Sedimentology, 52, 489-512.

Naylor, D., Jones, P. C., \& Clayton, G. (1978). The Namurian stratigraphy of Whiddy Island, Bantry Bay, West Cork. Geological Survey of Ireland Bulletin, 2, 235-253.

Naylor, D., Nevill, W. E., Ramsbottom, W. H. C., \& Sevastopulo, G. D. (1985). Upper Dinantian stratigraphy and faunas of the Old Head of Kinsale and Galley Head, south County Cork. Irish Journal of Earth Sciences, 7, 47-58.

Naylor, D., Higgs, K. H., Reilly, T. A., \& Sevastopulo, G. D. (1988). Dinantian and Namurian stratigraphy, Seven Heads Peninsula, County Cork. Irish Journal of Earth Sciences, 9, 1-17.

Naylor, D., Sevastopulo, G. D., \& Sleeman, A. G. (1989). Subsidence history of the South Munster Basin, Ireland. In R. S. Arthurton, P. Gutteridge \& S. C. Nolan (Eds.), The role of tectonics in Devonian and Carboniferous sedimentation in the British Isles (pp. 99-110). Leeds: Yorkshire Geological Society, Occasional Publication, 6.

Nemirovskaya, T. I. (1987). Conodonts of the lower part of the Donbas Bashkirian. Biull MOIP, Otdelenie Geological, 62/4, 106-126.

Nevill, W. E. (1957). The geology of the Summerhill basin, Co. Meath, Ireland. Proceedings of the Royal Irish Academy, Section B, 58, 293-303.

Nikitin, S. N. (1890). Carboniferous deposits of the Moscow region and artesian waters in the vicinity of Moscow. Transactions Geological Committee 5, 1-182 (in Russian). 
Nikolaeva, S. V., Alekseev, A. S., Kulagina, E. I., Gatovky, Y. A., Ponemareva, G. A., \& Gibshman, N. B. (in press). An evaluation of biostratigraphic markers across multiple geological sections in the search for the GSSP of the base of the Serpukhovian Stage (Mississippian). Palaeoworld. https://doi.org/10.1016/j.palwor.2019.01.006

Nolan, S. C. (1986). The Carboniferous Geology of County Dublin. Dublin: Unpublished Ph.D. thesis, University of Dublin.

Nudds, J. R. (1979). The Carboniferous coral Orionastraea in Ireland. Journal of Earth Sciences, 2, 65-70.

Owens, B., McLean, D., \& Bodman, D. (2004). A revised palynozonation of British Namurian deposits and comparisons with eastern Europe. Micropaleontology, 50, 89-103.

Owens, B., McLean, D., Simpson, K. R. M., Shell, P. M. J., \& Robinson, R. (2005). Mississippian palynostratigraphy, Scotland. Palynology, 29, 23-47.

Pickard, N. A. H., Jones, G. LL., Rees, J. G., Somerville, I. D., \& Strogen, P. (1992). Lower Carboniferous (Dinantian) stratigraphy and structure of the WalterstownKentstown area, Co. Meath. Geological Journal, 27, 35-58.

Pickard, N. A. H., Rees, J. G., Strogen, P., Somerville, I. D., \& Jones, G. LI. (1994). Controls on the evolution and demise of Lower Carboniferous carbonate platforms, northern margin of the Dublin Basin, Ireland. Geological Journal, 29, 93-117.

Pirlet, H., \& Conil, R. (1977). L'évolution des Archaediscidae viséens. Bulletin de la Société belge de Géologie, 82, 241-299 (preprint 1974).

Poty, E. \& Hance, L. (2006). Warnantian. Geologica Belgica, 9, 139-144.

Pracht, M., \& Somerville, I. D. (2015). A revised Mississippian lithostratigraphy of County Galway (western Ireland) with an analysis of carbonate lithofacies, 
biostratigraphy, depositional environments and palaeogeographic reconstructions utilising new borehole data. Journal of Palaeogeography, 4, 1-26.

Ramsbottom, W. H. C. (1969). Interim report of the Namurian Working Group. In Compte Rendue 6 ème Congrès International de Stratigraphie et de Géologie du Carbonifère, volume I (pp. 71-77). Sheffield, 1967.

Ramsbottom, W. H. C. (1974). Dinantian. In D. H., Rayner \& J. E. Hemingway, (Eds.), The Geology and Mineral Resources of Yorkshire (pp. 47-73). Leeds: Occasional Publication of the Yorkshire Geological Society.

Ramsbottom, W. H. C. (1981). Field guide to the boundary stratotypes of the Carboniferous stages in Britain. Leeds: Biennial Meeting of the Subcommission of Carboniferous Stratigraphy.

Ramsbottom, W. H. C., Calver, M. A., Eagar, R. M. C., Hodson, F., Holliday, D. W., Stubblefield, C. J., \& Wilson, R. B. (1978). A correlation of Silesian rocks in the British Isles. London: Special Report of the Geological Society of London, 10.

Rauser-Chernousova, D. M. (1948). Some new species of foraminifera of the Early Carboniferous deposits of the Submoscovite basin. Akademiya Nauk SSSR, Trudy Instituta Geologicheskikh Nauk, 62 (geologicheskaya seriya 19), 227-238 (in Russian)

Reitlinger, E. A. (1949). Smaller foraminifers in the lower part of the Middle Carboniferous of the Middle Urals and Kama River area. Izvestiya Akademii Nauk SSSR, Seriya Geologicheskaya, 6, 149-164 (in Russian).

Richards, B. C., \& Task Group. (2003). Progress report from the Task Group to establish a GSSP close to the existing Viséan-Serpukhovian boundary. Newsletter on Carboniferous Stratigraphy, 21, 6-10.

Richards, B. C., \& Task Group. (2017). Report of the Task Group to establish a GSSP close to the existing Viséan-Serpukhovian boundary. Newsletter on Carboniferous Stratigraphy, 33, 11-16. 
Riley, N. J., Varker, W. J., Owens, B., Higgins, A. C., \& Ramsbottom, W. H. C. (1987). Stonehead Beck a British proposal for the Mid-Carboniferous Boundary Stratotype. Courier Forschungsinstitut Senckenberg, 98, 159-177.

Robbie, J. A. (1955). The Carboniferous rocks of Edendork, Co. Tyrone. Bulletin of the Geological Survey of Great Britain, 8, 21-37.

Rose, W. C. C., \& Dunham, K. C. (1977). Geology and Hematite Deposits of South Cumbria. Economic Memoir of the Geological Survey of Great Britain, Sheets 58 \& part of 48. London: HMSO.

Sevastopulo, G. D. (2009). Chapter 11: Carboniferous: Mississippian (Serpukhovian and Pennsylvanian). In C. H. Holland \& I. S. Sanders (Eds.), The Geology of Ireland. 2nd edn. (pp. 269-294). Edinburgh: Dunedin Academic Press.

Sevastopulo, G. D., \& Barham, M. (2014). Correlation of the base of the Serpukhovian Stage (Mississippian) in NW Europe. Geological Magazine, 151, 244-253.

Sevastopulo, G. D., \& Wyse Jackson, P. N. (2009). Chapter 10. Carboniferous: Mississippian (Tournaisian and Viséan). In C. H. Holland \& I. S. Sanders (Eds.), The Geology of Ireland. 2nd edn. (pp. 215-268). Edinburgh: Dunedin Academic Press.

Shephard-Thorn, E. R. (1963). The Carboniferous limestone succession in North-West County Limerick, Ireland. Proceedings of the Royal Irish Academy, Section B: Biological, Geological and Chemical Science, 62, 267-294.

Shvetshov, M. S. (1932). General geological map of the European part of the USSR, sheet 58. North-western quadrangle. Gosnauchtekhizdat, Moscow. (in Russian).

Skompski, S., Alekseev, A., Meischner, D., Nemirovskaya, T., Perret, M.-F., \& Varker, W.J. (1995). Conodont distribution across the Viséan/Namurian boundary. Courier Forschungsinstitut Senckenberg, 188, 177-209.

Sleeman, A. G., \& Pracht, M. (1994). Geology of South Cork. A geological description of South Cork and adjoining parts of Waterford to accompany the bedrock geology 
1:100,000 scale map Series, sheet 25, South Cork. Dublin: Geological Survey of Ireland.

Sleeman, A. G., \& Pracht, M. (1999). Geology of the Shannon Estuary. A geological description of the Shannon Estuary region including parts of Clare, Limerick and Kerry, to accompany the Bedrock Geology 1:100 000 Scale Map Series, Sheet 17, Shannon Estuary. Dublin: Geological Survey of Ireland.

Smyth, L. B. (1950). The Carboniferous System in North County Dublin. Quarterly Journal of Geological Society of London, 105, 295-326.

Somerville, H. E. A. (1999). Conodont Biostratigraphy and Biofacies of Upper Viséan Rocks in Parts of Ireland. Dublin: Unpublished Ph. D. thesis, National University of Ireland, University College Dublin.

Somerville, H. E. A., \& Somerville, I. D. (1999). Late Viséan Conodont biostratigraphy and biofacies in Kingscourt area, Ireland. Bolletino della Società Paleontologica Italiana, 37, 443-464.

Somerville, I.D. (2016a). Chapter 4. The Lower Carboniferous of the Shannon Basin Region. In J. L. Best \& P.B. Wignall (Eds.), A Field Guide to the Carboniferous sediments of the Shannon Basin, western Ireland (pp. 48-78). Chichester: John Wiley \& Sons.

Somerville, I.D. (2016b). Chapter 5. Viséan coral biostromes and karsts of the Burren. In J. L. Best \& P.B. Wignall (Eds.), A Field Guide to the Carboniferous sediments of the Shannon Basin, western Ireland (pp. 76-96). Chichester: John Wiley \& Sons.

Somerville, I. D., \& Cózar, P. (2005). Late Asbian to Brigantian (Mississippian) foraminifera from south-east Ireland: comparison with Northern England assemblages. Journal of Micropalaeontology, 24, 131-144.

Somerville, I. D., \& Waters, C. N. (2011a). NW Ireland. In C. N., Waters, I. D., Somerville, N. S. Jones et al. (Eds.), A revised correlation of Carboniferous rocks in the British 
Isles (pp. 128-132). Dorchester: The Geological Society, London, Special Report 26.

Somerville, I. D., \& Waters, C. N. (2011b). Western Ireland. In C. N., Waters, I. D., Somerville, N. S. Jones et al. (Eds.), A revised correlation of Carboniferous rocks in the British Isles (pp. 123-137). Dorchester: The Geological Society, London, Special Report 26.

Somerville, I. D., \& Waters, C. N. (2011c). Dublin Basin. In C. N., Waters, I. D., Somerville, N. S. Jones et al. (Eds.), A revised correlation of Carboniferous rocks in the British Isles (pp. 138-143). Dorchester: The Geological Society, London, Special Report 26.

Somerville, I. D., Strogen, P., \& Jones, G. LL. (1992). Biostratigraphy of Dinantian limestones and associated volcanic rocks of the East Limerick Syncline. Geological Journal, 27, 201-220.

Somerville, I. D., Jones, G. LL., \& Philcox, M. E. (1996a). Supra-Waulsortian Workshop. Dublin: Irish Association for Economic Geology.

Somerville, I. D., Strogen, P., Jones, G. LI., \& Somerville, H. E. A. (1996b). Late Viséan buildups at Kingscourt, Ireland: possible precursors for Upper Carboniferous bioherms. In P. Strogen, I. D. Somerville \& G. LL. Jones (Eds.), Recent Advances in Lower Carboniferous Geology (pp. 127-144). Oxford: Geological Society, London, Special Publications, 107.

Somerville, I. D., Waters, C. N., \& Collinson, J. D. (2011). South Central Ireland. In C. N., Waters, I. D., Somerville, N. S. Jones et al. (Eds.), A revised correlation of Carboniferous rocks in the British Isles (pp. 144-152). Dorchester: The Geological Society, London, Special Report 26.

Stephenson, M. H., Angiolini, L., Cózar, P., Jadoul, F., Leng, M. J., Millward, D., \& Chenery, S. (2010). Northern England and Serpukhovian (early Namurian) farfield responses to southern hemisphere glaciation. Journal of the Geological Society, London, 167, 1171-1184. 
Strank, A. R. E. (1981). Foraminiferal biostratigraphy of the Holkerian, Asbian and Brigantian stages of the British Lower Carboniferous. Manchester: Ph. D. thesis, University of Manchester.

Strogen, P., Somerville, I. D., Jones, G. Ll., \& Pickard, N. A. H. (1995). The Lower Carboniferous (Dinantian) stratigraphy and structure of the Kingscourt Outlier, Ireland. Geological Journal, 30, 1-23.

Strogen, P., Somerville, I. D., Pickard, N. A. H., Jones, G. LI., \& Fleming, M. (1996). Controls on ramp, platform and basin sedimentation in the Dinantian of the Dublin Basin and Shannon Trough, Ireland. In P. Strogen, I. D. Somerville \& G. LL. Jones (Eds), Recent Advances in Lower Carboniferous Geology (pp. 263-279). Oxford: Geological Society, London, Special Publications, 107.

Tietzsch-Tyler, D., \& Sleeman, A. G. (1994). Geology of Carlow - Wexford. A geological description to accompany the Bedrock Geology 1:100 000 Scale Map Series, Sheet 19, Carlow - Wexford., with contributions from McConnell, B. J., Daly, E. P., Flegg, G, A. M., O'Connor, P. J., Philcox, M. E. \& Warren, W. P., Edited by B. McConnell. Dublin: Geological Survey of Ireland.

Vachard, D. (1988). Pour une classification raisonnée et raisonnable des Archaediscidae (Foraminifera, Carbonifère inférieur-moyen). Revue de Paléobiologie, volume spécial $n^{\circ} 2$, Benthos' 86, 103-123.

Varker, W. J. (1964). The conodont faunas and stratigraphy of the Yoredale Series in the Askrigg and Alston regions. Sheffield: Unpublished Ph.D. University of Sheffield.

Varker, W. J. (1994). Multielement conodont faunas from the proposed MidCarboniferous boundary stratotype locality at Stonehead Beck, Cowlings, North Yorkshire, England. Annales de las Société géologique de Belgique, 116, 301-321.

Vdovenko, M. V. (2001). Atlas of foraminifera from the Upper Viséan and Lower Serpukhovian (Lower Carboniferous) of the Donets Basin (Ukraine). Abhandlungen und Berichte für Naturkunde, 23, 93-178. 
Wagner, R. H., \& Higgins, A. C. (1979). The Carboniferous of the USSR: its stratigraphic significance and outstanding. In R. H. Wagner, A. C. Higgins \& S. V. Meyen (Eds.), The Carboniferous of the USSR (pp. 5-22). Leeds: Yorkshire Geological Society, Occasional Publication 4.

Waters, C. N., \& Condon, D. J. (2012). Nature and timing of Late Mississippian to MidPennsylvanian glacio-eustatic sea level changes of the Pennine Basin, UK. Journal of the Geological Society, London, 169, 37-51.

Waters, C. N., \& Somerville, I.D., (2011). South Munster Basin. In C. N., Waters, I. D., Somerville, N. S. Jones et al. (Eds.), A revised correlation of Carboniferous rocks in the British Isles (pp. 153-155). Dorchester: The Geological Society, London, Special Report 26.

Waters, C. N., Somerville, I. D., Stephenson, M. H., Cleal, C. J., \& Long, S.L. (2011). Biostratigraphy. In C. N., Waters, I. D., Somerville, N. S. Jones et al. (Eds.), A revised correlation of Carboniferous rocks in the British Isles (pp. 11-22). Dorchester: The Geological Society, London, Special Report 26.

Waters, C. N., Millward, D., \& Thomas, C. W. (2014). The Millstone Grit Group (Pennsylvanian) of the Northumberland-Solway Basin and Alston Block of northern England. Proceedings of the Yorkshire Geological Society, 60, 29-51.

Wignall, P. B., \& Best, J. L. (2000). The Western Irish Namurian Basin reassessed. Basin Research, 12, 59-78.

Wignall, P. B., Somerville, I. D., \& Braithwaite, K. (2016). Chapter 6. The Clare Shales. In J. L., Best, \& P. B. Wignall (Eds.), A Field Guide to the Carboniferous sediments of the Shannon Basin, western Ireland (pp. 97-111). Chichester: John Wiley \& Sons.

Wilson, H. E., \& Robbie, J. A. (1966). Geology of the Country around Ballycastle. Memoir of the Geological Survey of Northern Ireland, Sheet 8 (Northern Ireland). Belfast: Geological Survey of Northern Ireland. 
Zandkarimi, K., Vachard, D., Najafian, B., Hamdi, B., \& Mosaddegh, H. (2017). ViséanSerpukhovian (Mississippian) archaediscoid foraminifers of the northern Alborz, Iran. Neues Jahrbuch für Geologie und Paläontologie Abhandlungen, 286, 105123. 


\section{Figure Captions}

Table 1 Location of selected stratigraphic sections mentioned in the text and illustrated material.

Figure 1 Map of Serpukhovian outcrops in Ireland with the location of the main Carboniferous basins and important sections mentioned in the text.

Figure 2 Lithostratigraphical correlation of Serpukhovian Irish rocks. Some highlighted members are in italics font. Horizontal striped bands correspond to hiatuses or absence of strata. Abbreviation Lissyl. = Lissylisheen .

Figure 3 Selected archaediscids from the unit 3 of the Clogrenan Formation (scale bar 100 microns). a-b, f, i sample Pc889, bed 15, Clogrenan Quarry; c-d, r-t sample Pc893, bed 20, Clogrenan Quarry; e, g-h sample Pc951, top of bed 1, Bannagogle Quarry; j-m, p-q sample Pc1383, bed 8, Guileen-1 Borehole; $n$ bed 44 and o bed 53, Clogrenan Quarry (location of bed in Cózar \& Somerville, 2005). [Thin-sections containing all the illustrated foraminifers in Figs. 3 to 9 are housed in the P. Cózar's palaeontological collection in the Geology Faculty, Universidad Complutense de Madrid, Spain]. (a-d) Neoarchaediscus gregorii. (e) Neoarchaediscus gregorii acutiformis? (f) Planospirodiscus aff. minimus. (g) Planospirodiscus minimus. (h-i) Planospirodiscus sp. (j-k) Neoarchaediscus postrugosus form 1. (I-m) Neoarchaediscus postrugosus? form 1. (n-o) Neoarchaediscus postrugosus form 2. (p) Planospirodiscus sp. (q) Planospirodiscus taimyricus, Pc1383. (r) Planospirodiscus aff. taimyricus. (s) Tubispirodiscus cf. simplissimus. (t) Tubispirodiscus sp. 1.

Figure 4 Diagram to show FAD of key foraminiferal and algal taxa in shallow-water platform limestone successions in Ireland containing Serpukhovian assemblages and their correlation with foraminiferal assemblages in northern England (Alston Block) (note that scale is half than that for the Irish sections) and the Russian substages (after Cózar \& Somerville, 2004, 2013, 2014, 2016). Well-established correlations are in solid lines, and inferred position of the correlations are in dotted lines. Clogrenan Formation 
is a composite section of the Clogrenan Quarry and Guileen-1 Borehole (after Cózar \& Somerville, 2005); Slievenaglasha is a composite section of the Slievenaglasha and Clooncloose sections for the Balliny and Fahee North Member (Gallagher et al., 2006) Lisdoonvarna Quarry for the Ballyelly Member, Gowlaun River for the Lissylisheen Member, and Kilnamona section for the Magowna Formation; Deer Park Formation is a composite section of the Barley Hill Quarry, Deer Park South and Poulmore Scarp Quarry (Somerville \& Somerville, 1999; Cózar et al., 2005a); Carganamuck Limestone Formation is based on Carganamuck Quarry (Cózar et al., 2005a); Rockdale Limestone Formation is based on Cookstown Quarry (Cózar et al., 2005a); the Leitrim Group is a composite section of the Aghagrania River section (Meenymore Fm), Sruh Croppa River section (Bellavally and Carraun Shale formations, and Altvenagh River section (Sheena Shale Member) in County Fermanagh (Cózar et al. 2006). Lithological abbreviations: P.- Pendleian; Tu- Tullyskeherny Member; Sr - Sraduffy Member; Lu - Lugasnaghta Shale Member; Sh - Sheena Shale Member; Co - Corry Member; De - Derreens Limestone Member; DT - Doagh Limestone and Tawnyunshinagh Limestone members; $\mathrm{Ar}$ - Ardvarney Limestone Member; Sn - Sranagross Member; Ca - Camderry Member. Foraminiferal abbreviations: At - Archaediscus at tenuis stage; $\mathrm{Bp}$ - Biseriella parva; $\mathrm{Br}$ Brenckleina; Bw - Brownediscus; Cc - Cepekia cepeki; Co - Calcifolium okense; $\mathrm{Cl}$ Climacammina; Ef - Eostaffellina; Eg - Eosigmoilina; Es - Endothyranopsis sphaerica; Jt Janischewskina typica; Mt - "Millerella" tortula; Ng - Neoarchaediscus gregorii; Np1 Neoarchaediscus postrugosus form 1; Np2 - Neoarchaediscus postrugosus form 2; Ns Neoarchaediscus shugorensis; Pm - Planospirodiscus minimus; Pt - Planospirodiscus taimyricus; Pa - Planospirodiscus aff. taimyricus; Ta - Tubispirodiscus attenuatus; Ts Tubispirodiscus simplissimus.

Figure 5 Selected foraminifers from the Ballyelly Member, Slievenaglasha Formation, Lisdoonvarna Quarry. Specimens b, c, f, $5 \mathrm{~m}$ below the top, specimens a, $d, h, 4.7 \mathrm{~m}$ below the top, and specimen $g$ at the top of the member (scale bar 100 microns). (a-b) Neoarchaediscus parvus. (c-d) Asteroarchaediscus rugosus. (e) Neoarchaediscus postrugosus? form 1 (oblique section). (f) Neoarchaediscus postrugosus form 1. (g) Neoarchaediscus postrugosus form 2. (h) Tubispirodiscus sp. (primitive form). 
Figure 6 Selected foraminifers from the Lissylisheen Member Slievenaglasha Formation, Gowlaun river section (scale bar 100 microns). (a) Neoarchaediscus shugorensis. (b) Neoarchaediscus postrugosus form 2. (c) Neoarchaediscus gregorii acutiformis. (d) Neoarchaediscus sp. 1. (e-f) Planospirodiscus aff. taimyricus. (g-h) Planospirodiscus taimyricus. (i) Tubispirodiscus cf. cornuspiroides (juvenile). (j-k) Tubispirodiscus sp. 1. (I) Tubispirodiscus simplissimus. (m) Tubispirodiscus aff. simplissimus. (n) Cepekia cepeki. (o) Eosigmoilina cf. robertsoni.

Figure 7 Selected foraminifers from the Magowna Formation at Kilnamona section, a-g. bed 2; h-m, bed 3; n-aa, bed 4 of Skompski et al. (1995) (scale bar 100 microns). (a) Tubispirodiscus sp. 1. (b) Tubispirodiscus simplissimus. (c) Neoarchaediscus postrugosus form 1. (d) Planospirodiscus sp. 2. (e) Planospirodiscus sp. 3. (f) Planospirodiscus minimus. (g) Neoarchaediscus shugorensis. (h) Tubispirodiscus simplissimus. (i) Brownediscus? sp. 1. (j) Neoarchaediscus gregorii acutiformis. (k) Asteroarchaediscus rugosus. (I) Planospirodiscus sp. 1. (m) Archaediscus sp. with some final whorls at tenuis stage. (n) Tubispirodiscus sp. 1. (o) Planospirodiscus sp. 1. (p) Brownediscus? sp. 2. (q) Planospirodiscus minimus. (r) Tubispirodiscus attenuatus. (s) Planospirodiscus sp. 3. (t) Neoarchaediscus? sp. (u) Planospirodiscus sp. 4. (v) Tubispirodiscus sp. (w-x) Brenckleina cf. rugosa. (y-z) Eosigmoilina? sp. (аa) Eosigmoilina robertsoni.

Figure 8 Selected foraminifers from Poulmore Scarp Quarry (Deer Park Formation). (scale bar 100 microns). c, $f$ at $3.1 \mathrm{~m}$ above the base of the quarry, j-k at $3.8 \mathrm{~m}, \mathrm{~g}, \mathrm{~m}, \mathrm{n}$ at $6.8 \mathrm{~m}, \mathrm{~h}, \mathrm{I}, \mathrm{o}$, at $7.4 \mathrm{~m}, \mathrm{a}, \mathrm{d}$ at $9.1 \mathrm{~m}$, and b, e, I at $10.8 \mathrm{~m}$ above the base of the quarry. Sample number means metres above the base of this disused quarry. (a-b) Planospirodiscus aff. taimyricus. (c) Neoarchaediscus postrugosus form 2. (d-e) Neoarchaediscus shugorensis. (f) Tubispirodiscus cornuspiroides? (g) Eosigmoilina robertsoni. (h) Brenckleina sp. (i) Brenckleina rugosa. (j-l) Archaediscus sp. at tenuis stage. (m) Eostaffellina ex gr. paraprotvae. (n) Eostaffellina sp. (o) Eostaffellina decurta.

Figure 9 Selected archaediscids from Cuilcagh Mountains. a-h sample Pc2453, Tullyskeherny Member of the Bellavally Formation (scale bar 100 microns). i-I sample Pc2467, Sheena Shale Member of the Bellavally Formation, $m-n, p-q, t-u$, sample 
Pc2458 and o, r-s, sample Pc2459, Derreens Limestone Member of the Carraun Shale Formation (see location of samples in Cózar et al., 2006). (a) Planospirodiscus sp. (b-c) Planospirodiscus aff. taimyricus. (d-e) Neoarchaediscus gregorii. (f-h) Neoarchaediscus postrugosus form 2. (i) Planospirodiscus minimus. (j) Neoarchaediscus postrugosus form 2 (oblique section). (k-I) Planospirodiscus taimyricus. (m) Neoarchaediscus postrugosus? - note that flanks of the test are more similar to Planospirodiscus. (n-o) Neoarchaediscus postrugosus form 2. (p-q) Tubispirodiscus attenuatus. ( $r$ ) Neoarchaediscus shugorensis. (s-t) Evolved form of Tubispirodiscus with 3-4 whorls at tenuis stage. (u) Archaediscus sp. at tenuis stage.

Figure 10 Selected foraminifers from the Main Limestone (Ballycastle Group), sample Pc2300 (scale bar 100 microns). (a) Neoarchaediscus aff. postrugosus form 2. (b) Neoarchaediscus postrugosus form 2. (c) Planospirodiscus cf. taimyricus. (d) Planospirodiscus sp. 1. (e) Eostaffellina aff. decurta. 


\begin{tabular}{|c|c|c|}
\hline Stratigraphic section & Lithological unit & Irish Grid coordinates \\
\hline Aghagrania River & Meenymore Formation & [M 996 120] \\
\hline Almush Stream & Almush Shale Member (Deer Park Fm) & [N 788 871] \\
\hline Altvenagh River & Sheena Shale Member (Bellavally Fm) & [H 119 298] \\
\hline Ballytrea Borehole & upper Rockdale Limestone Formation & [N 870744$]$ \\
\hline Bannagogle Quarry & upper Clogrenan Formation & [S 661645$]$ \\
\hline Barley Hill Quarry & lowermost Deer Park Formation & [N 827 965] \\
\hline Carganamuck Quarry & Carganamuck Formation & [H 878 498] \\
\hline Clogrenan Quarry & lower Clogrenan Formation & [S 688720$]$ \\
\hline Clooncloose & lower Slievenaglasha Formation & [R 2835 9506] \\
\hline Cookstown Quarry & upper Rockdale Limestone Formation & [H 801 748] \\
\hline Deer Park South & Deer Park Formation & [N 823 962] \\
\hline Dunamase Quarry & upper Clogrenan Formation & [S 542 993] \\
\hline Gowlaun River (= St Brendan's Well) & Lissylisheen Member (Slievenaglasha Fm) & [R 1450 9840] \\
\hline Guileen-1 Borehole & upper Clogrenan Formation & [S 572 915] \\
\hline Kilnamona & Magowna Formation & [R27821 80339 ] \\
\hline Lisdoonvarna Quarry (N67) & Ballyelly Member (Slievenaglasha Fm) & [R 1540 9950] \\
\hline Magowna Waterfall & Magowna Formation & [12890 18220] \\
\hline North Star Dyke at Ballycastle & Main Limestone (Ballycastle Group) & [D148 419] \\
\hline Poulmore Scarp Quarry & uppermost Deer Park Formation & [N 823 959] \\
\hline Pollasumera River & Meenymore Formation & [H 129 323] \\
\hline Slievenaglasha & lower Slievenaglasha Formation & [R 3126 9835] \\
\hline Sruh Croppa River & Tullyskeherny Member (Bellavally Fm) & [H 104 317] \\
\hline Sruh Croppa River & Derreens Limestone Member (Carraun Shale Fm) & [H 098 307] \\
\hline Vigo Cave (W of Inchiquin Lough) & Lissylisheen Member (Slievenaglasha Fm) & [R 260 905] \\
\hline Vigo Pothole & Lissylisheen Member (Slievenaglasha Fm) & {$\left[\begin{array}{lll}R 260 & 907]\end{array}\right.$} \\
\hline
\end{tabular}




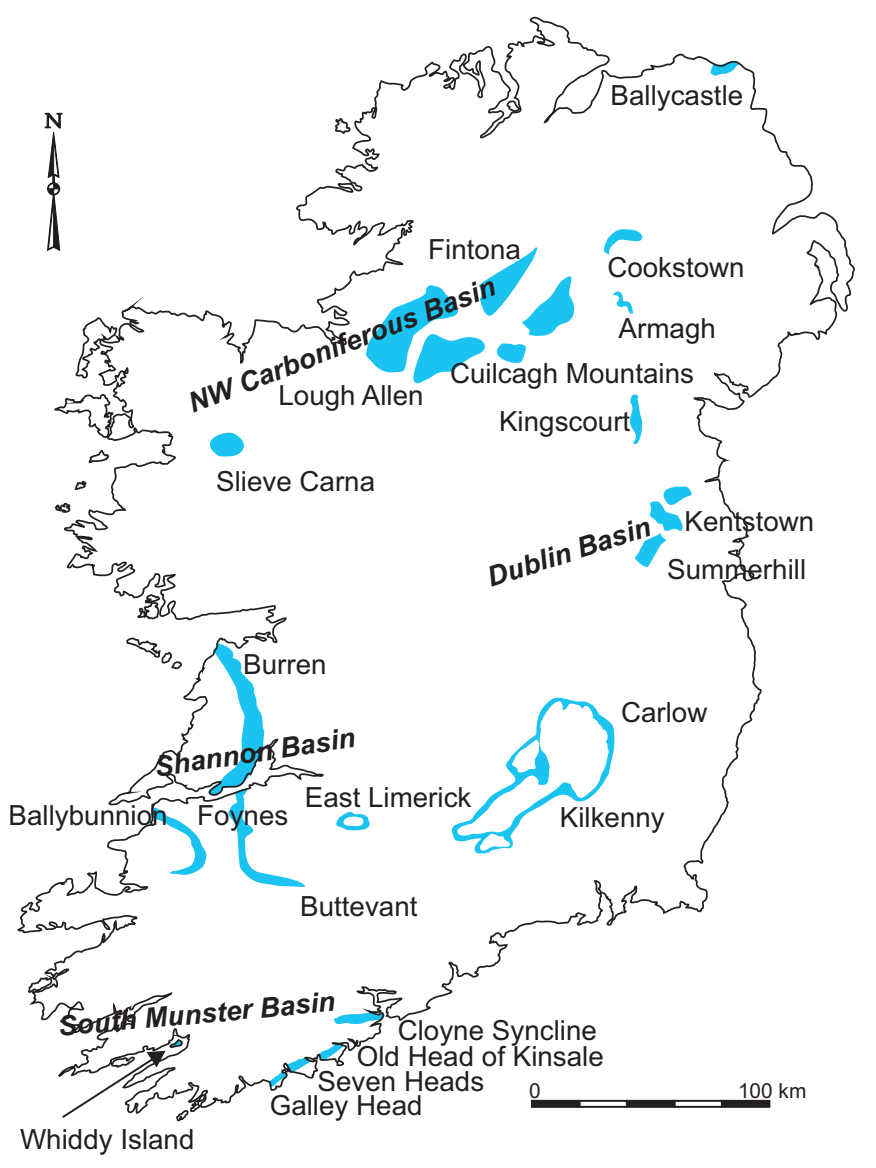




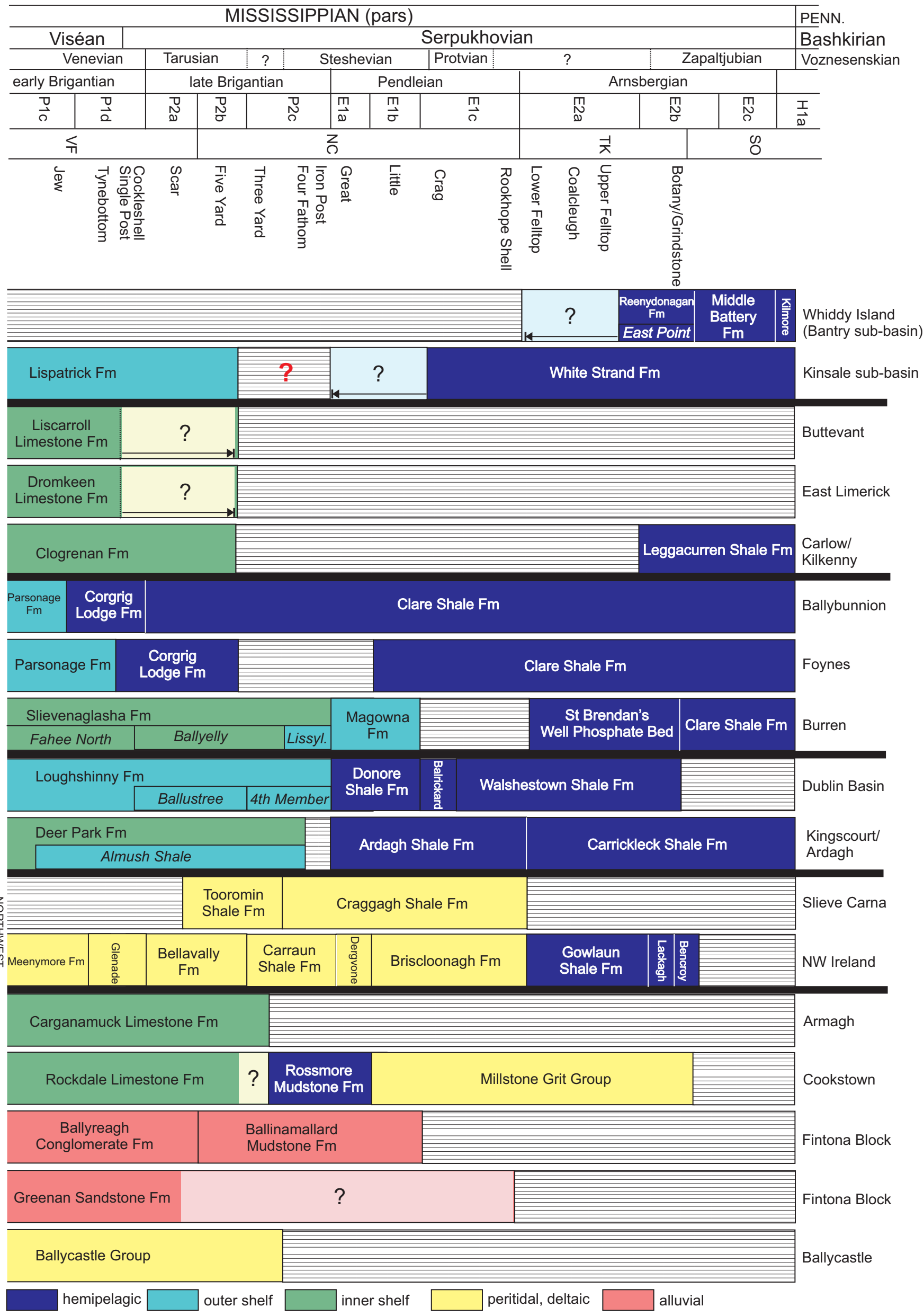



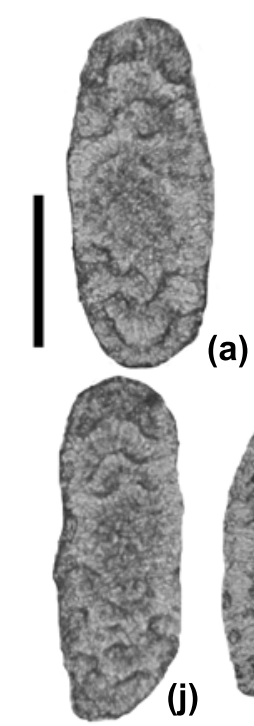

(b)

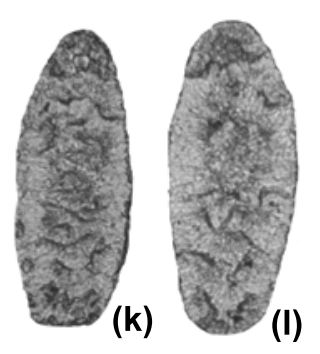

(c)

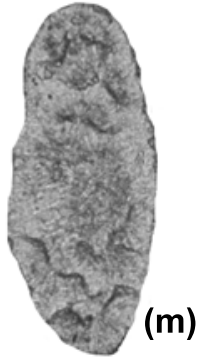

(d)

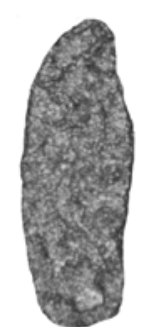

(e)

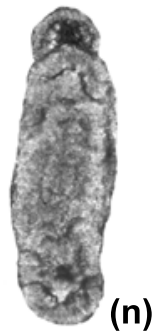

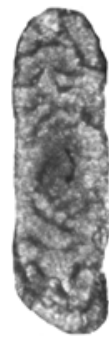

(f)

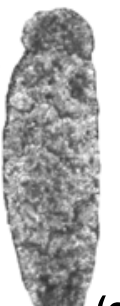

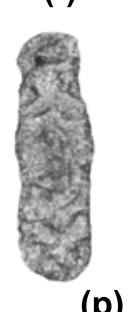

(p)
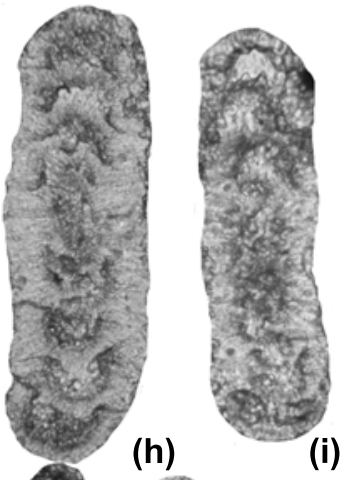

(g)
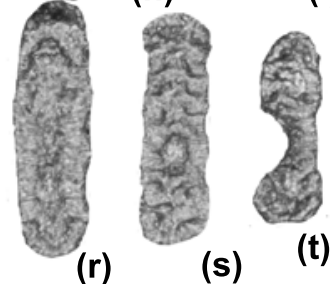

(s) (t) 


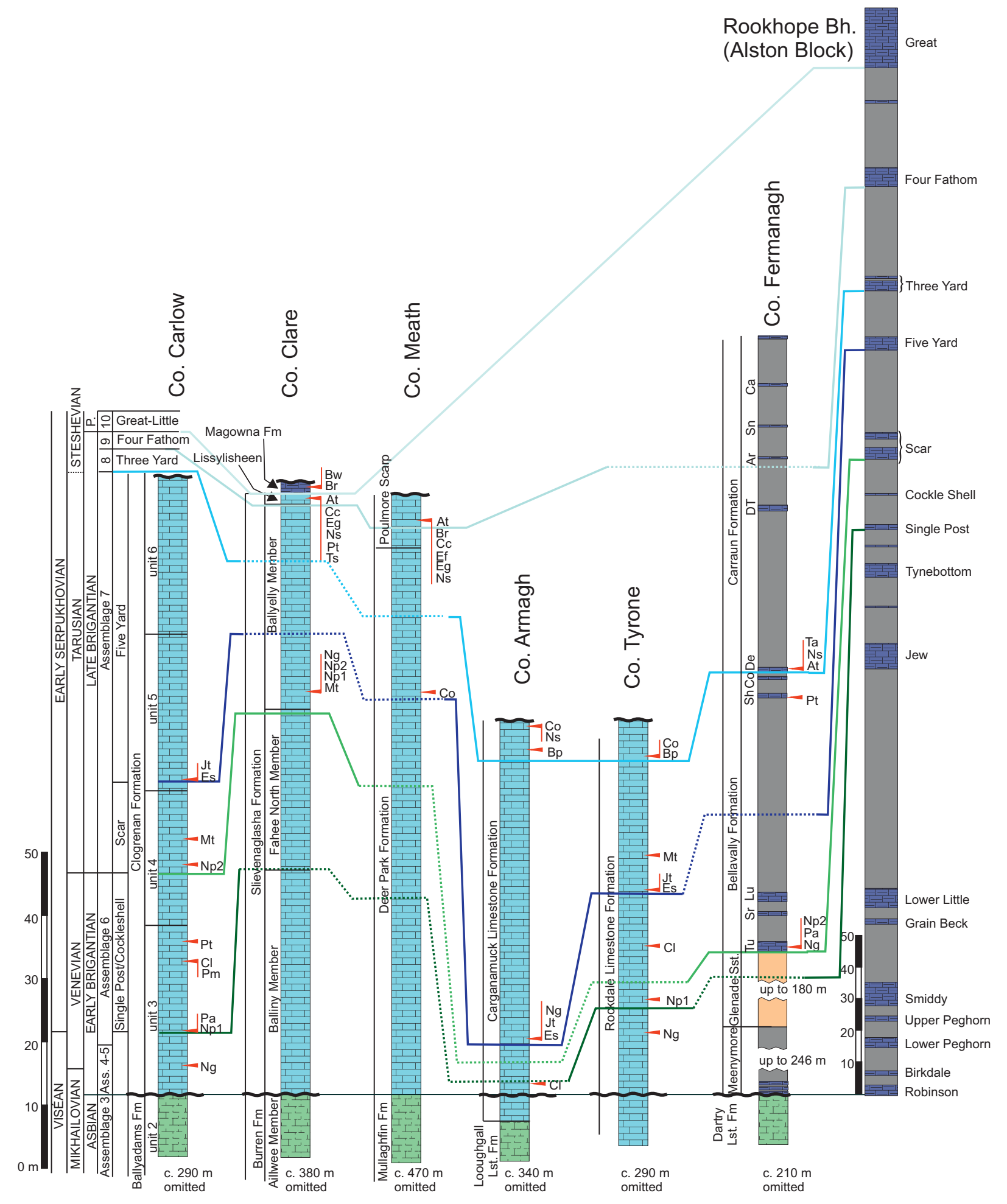


(a)
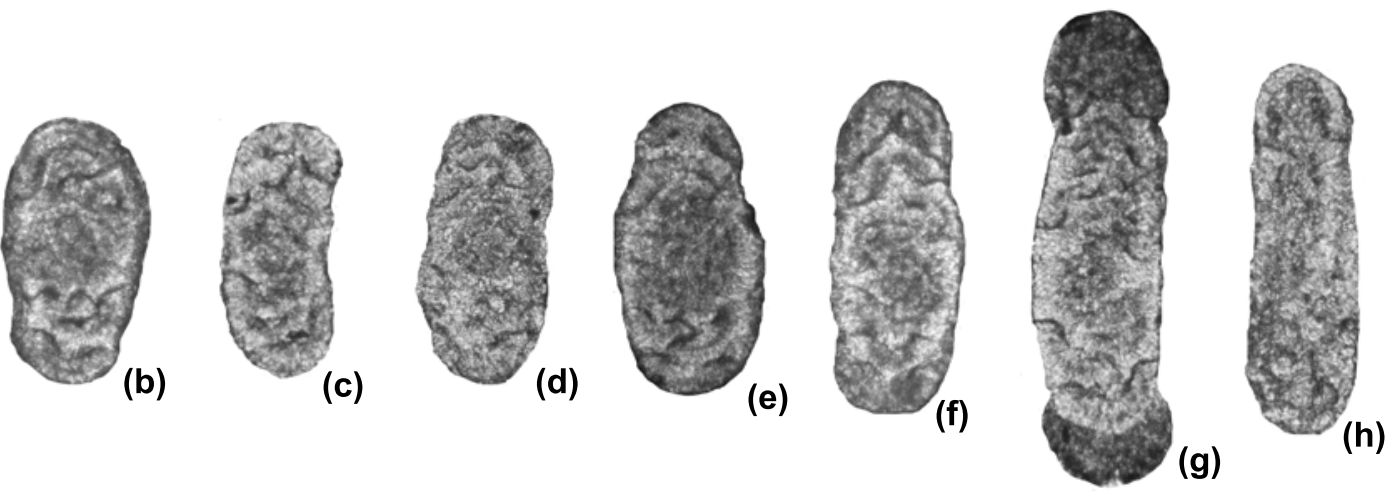


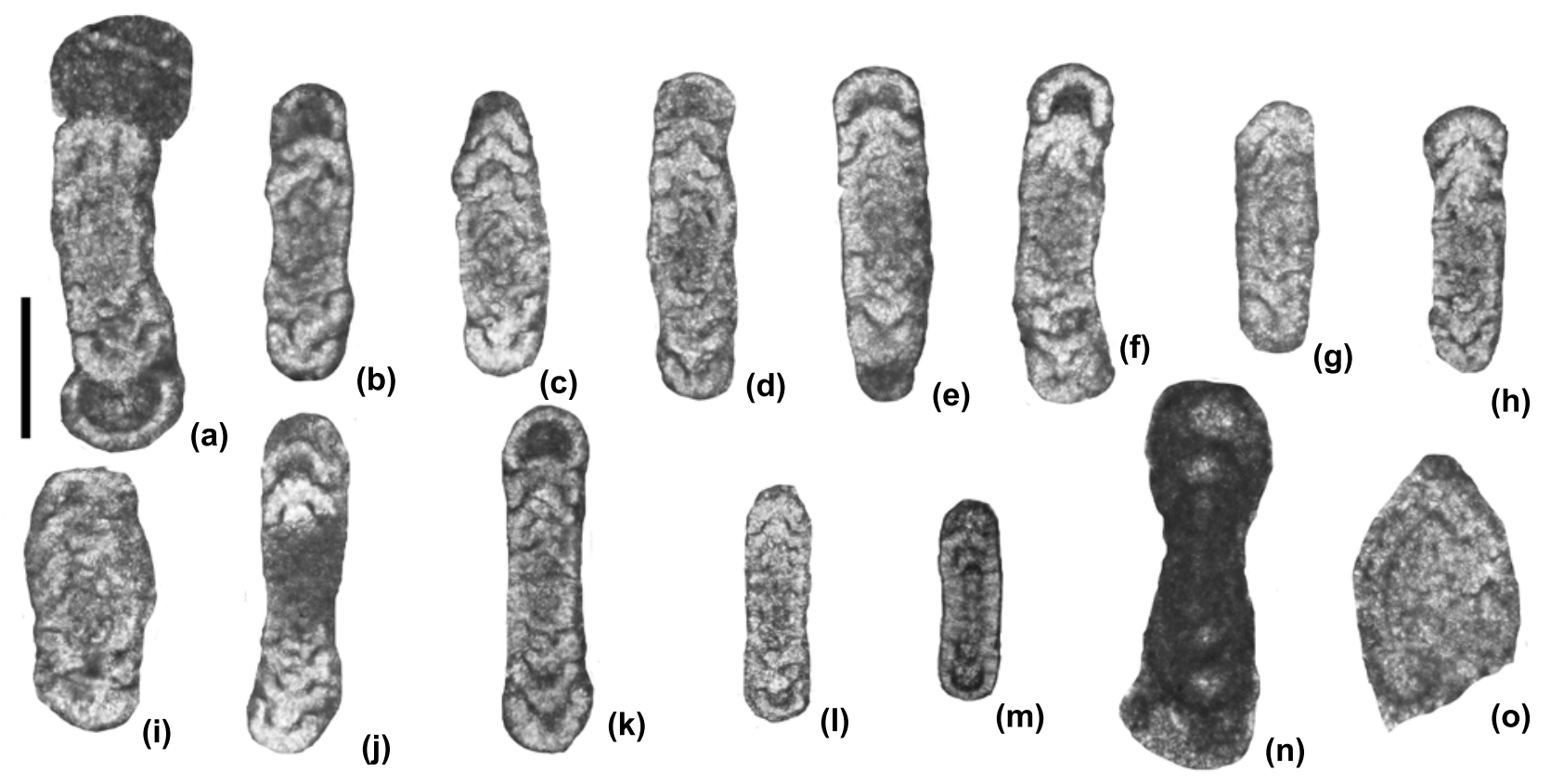




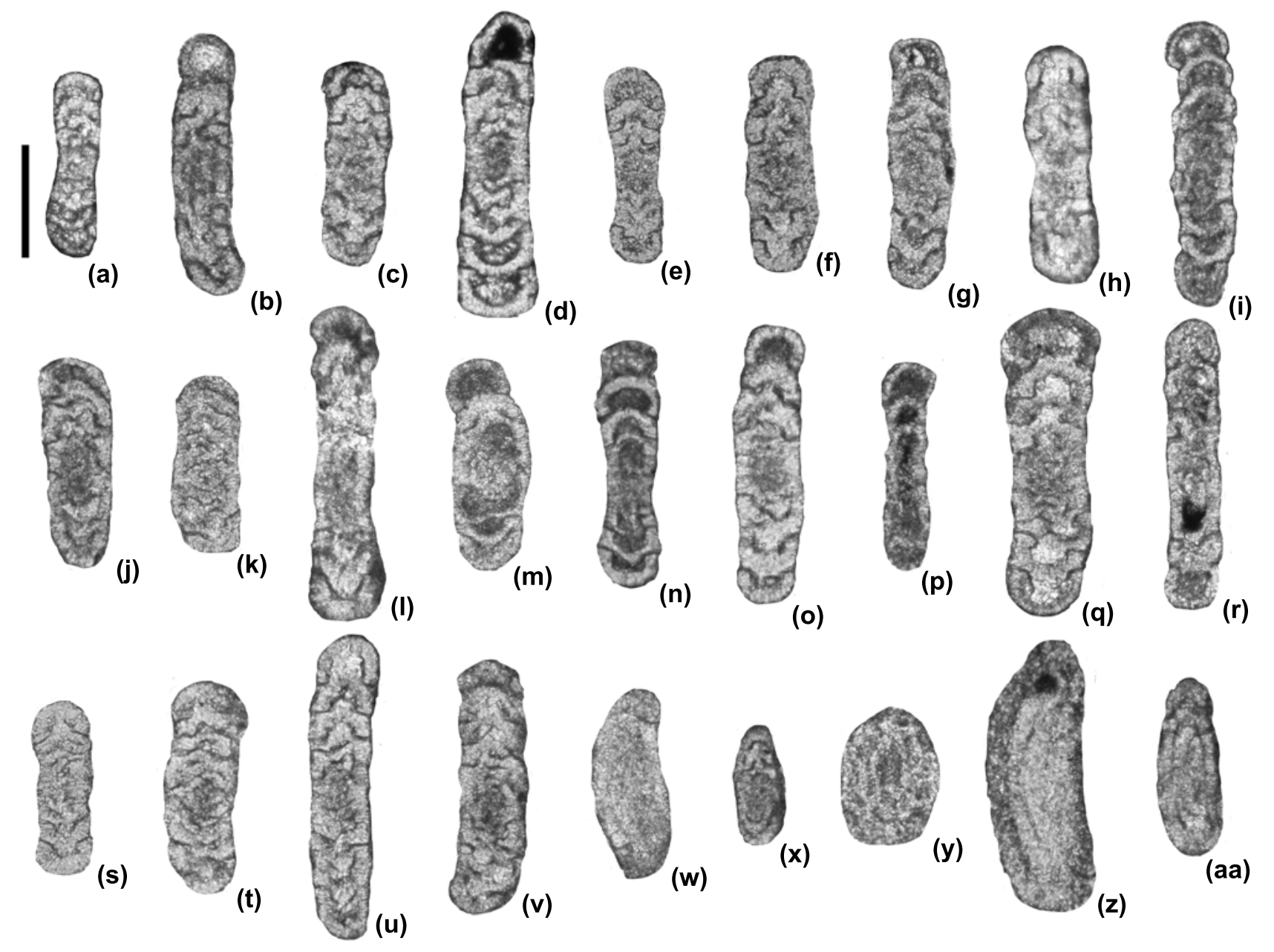



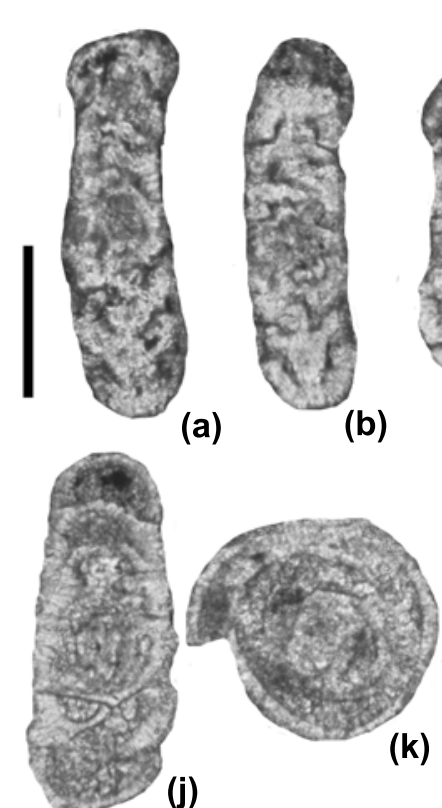

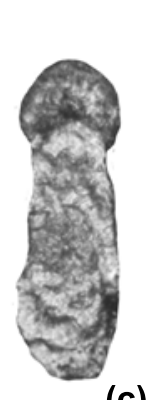

(c)
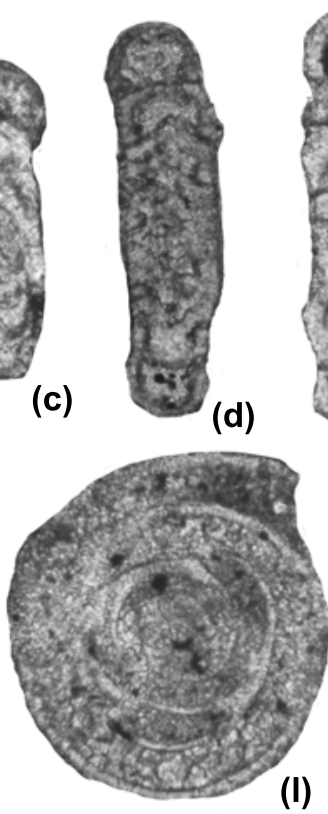

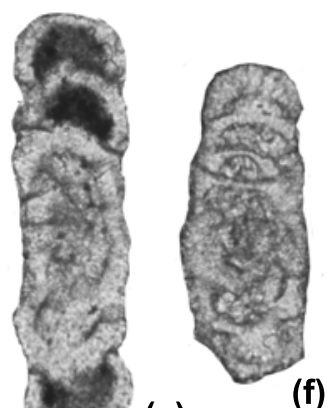

(f)
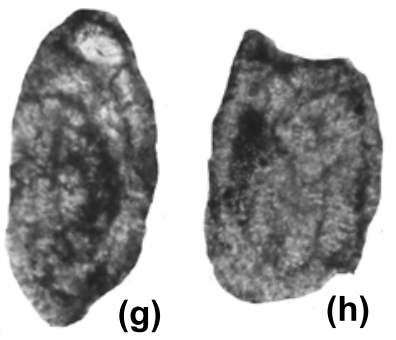

(h)
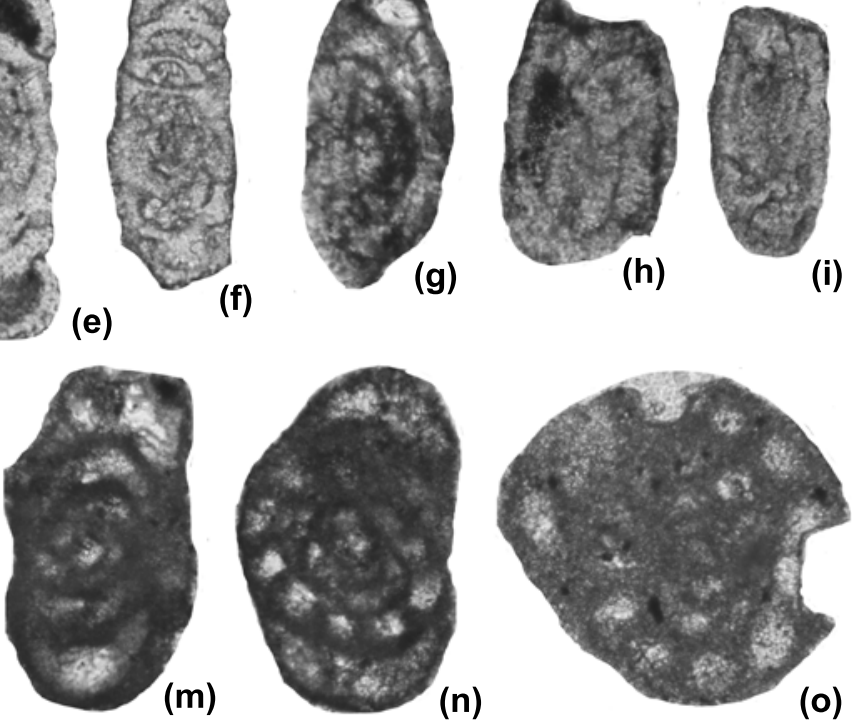


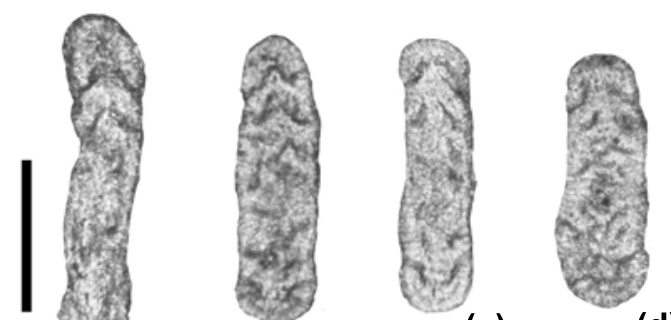

(a)

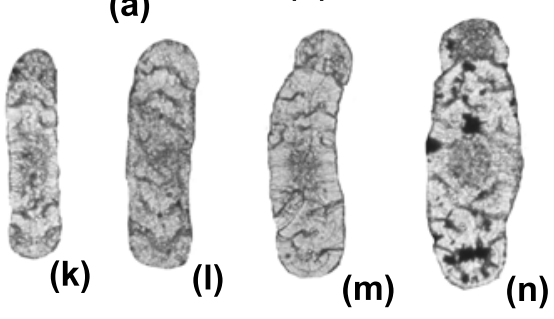

(d)

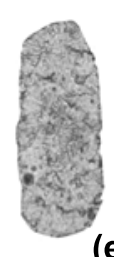

(e)

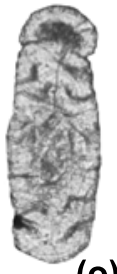

(o)

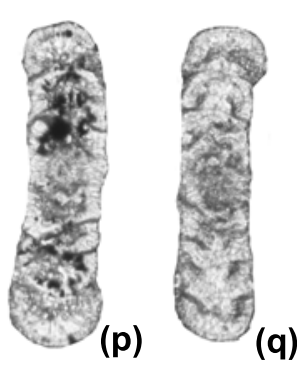

(q)
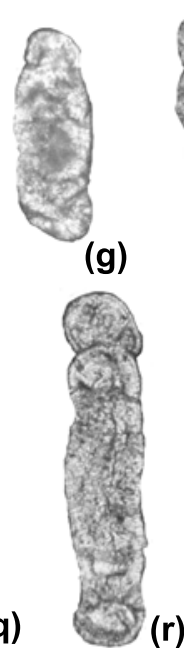

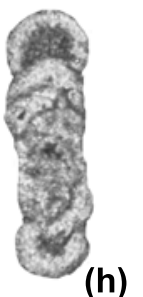

(h) (i)
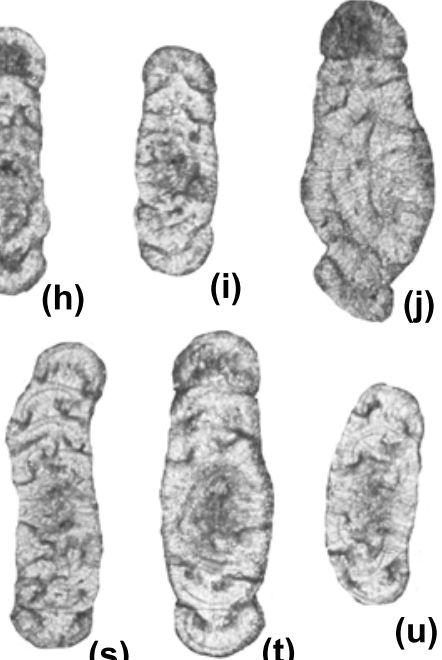

(u) 


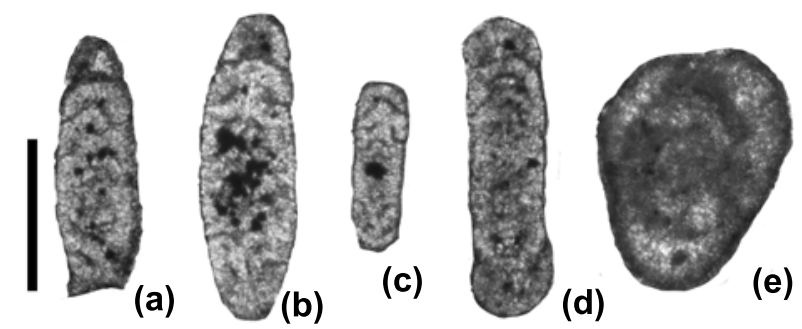

